\title{
CALOUSTE GULBENKIAN, HIS MĪNA' 'T WARE, AND THE CHANGING ISLAMIC ART MARKET IN THE EARLY TWENTIETH CENTURY
}

This article aims to provide a clearer understanding of the emergence of the market for Islamic art in the early decades of the twentieth century through a study of the changing purchasing habits of one European collector, specifically in his acquisition of $\bar{m} \bar{i} \bar{a} \bar{\iota}$ ware. ${ }^{1}$ Despite the narrow scope, this approach allows for a coherent, focused study while engaging with the leading dealers, agents, and auction houses of the time. These were located primarily in Paris and, to lesser extent, New York and London, in the key period during which the Islamic art market became a major part of the broader art and antiquities business. This early period was the colonial heyday of collecting Islamic art, ${ }^{2}$ and saw the establishment of a canon of popular items - led by contemporary tastemakers, collectors, and dealers - which continues to this day. ${ }^{3}$

Before addressing the core material, it is important to examine some of the key terms, as the accepted vocabulary also developed in the same period. While the term "Islamic art" is now widely accepted (despite its imperfections), ${ }^{4}$ there was no clear consensus as to which words should be used to refer to such material in the late nineteenth and early twentieth centuries. In the latter decades of the nineteenth century, the archaeologist Émile Prisse d'Avennes (1807-79) used the term "l'art Arabe" for his work on Islamic Cairo, but the term "Saracenic art" was also in use. ${ }^{5}$ In the major exhibition of 1910 in Munich, the term "Mohammadan" was used, ${ }^{6}$ and the same term was employed in 1922 when Rudolph M. Riefstahl (1880-1936) published the Islamic ceramics in the Parish-Watson collection. ${ }^{7}$ However, there was also an increasing use of nationalist or ethnic terminology, especially in the commercially desirable field of Persian art. ${ }^{8}$ There was an exhibition in London in 1885 that deployed the terms "Arab" and "Persian," followed by the major International Exhibition of Persian Art at Burlington House in $1931 .{ }^{9}$ A few years later, the seeming supremacy of Persian over all other ethno-nationalist categories was further reinforced with the publication of $A$ Survey of Persian Art, edited by Arthur Upham Pope (1881-1969) and Phyllis Ackerman (1893-1977). ${ }^{10}$ Alongside the terms "Arab" and "Persian" in the commercial market, of which Paris was the center, "art Musulman" was common as well.11 At least one auction house also employed the term "Oriental" to distinguish material produced in the Islamic world from the European objects in their sale, which were categorized as "Occidental." ${ }^{2}$ One of the earliest cases of the term "Islamic" being used in the context of art came with the establishment of an Islamic department at the Bode Museum in Berlin in $1904 .{ }^{13}$

Alongside changing terms for the wider market, min $\bar{a} \bar{\imath}$ ware has also seen a shift in nomenclature over the last century. Initially referred to as Rhages ware after the old name for the ancient city of Rayy, located just south of Tehran, where most of the early finds were made, ${ }^{14}$ these items were to become almost universally known as mina $\bar{\imath} \bar{\imath}$ (enameled) ware from the 193os onward. ${ }^{15}$ The original term for such items, used by Abu'l Qasim in his treatise of 1301, was haft rang (seven colors), ${ }^{16}$ but this term is now rarely used. ${ }^{17}$ Despite the inclusion of $\min \bar{a} \bar{\imath}$ ware in a wide range of both general and specific publications on the subject of Islamic art, and the categorization of other well-known types of vessels into clearly identifiable stylistic groupings, ${ }^{18}$ no such process has been applied effectively to minā $\bar{\imath}$ ware. ${ }^{19}$

(C) RICHARD PIRAN MCCLARY, 2020 | DOI:10.1163/22118993-00371P13

This is an open access article distributed under the terms of the CC BY 4.o license. 
The newly developed categories of numbered styles used throughout this article are based on the close examination of several thousand sherds and vessels in a large number of public and private collections around the world over the course of the last ten years. The different styles, shown in a tabulated form in the appendix (p. 337), are based on a combination of the various distinctive inscription band styles and their related styles of ornament on the rest of the vessel, as well as the underlying base glaze, as some styles are only found on turquoise base glazed wares, while others are only found on white base glazed pieces. In addition, there is also a distinctive style featuring minnà $\bar{\iota}$ decoration on an unglazed clay body, and one that features both luster and minā' $\bar{\imath}$ decoration on the same vessel.

The Armenian oil magnate Calouste Sarkis Gulbenkian (1869-1955), who considered himself an "Oriental collector," 20 was one of the major early collectors of minnà $\grave{\iota}$ ware. Born in the Istanbul neighborhood of Scutari (Üsküdar), he left the Ottoman empire to study in France and then in England, becoming a British citizen in 1902. He resided primarily in Paris and London prior to moving to Lisbon in $1942 .{ }^{21}$ Calouste Gulbenkian was a prolific art collector, with interests in a vast range of different materials, from Lalique glass to ancient Greek coins, old master paintings, and French furniture. However, the largest category of items in his collection, and the one that he consistently collected throughout his life, was art of the Islamic world. ${ }^{22}$

Unlike most contemporaneous art collectors, such as Parish Watson, ${ }^{23}$ Isaac D. Fletcher (1844-1917), and Frédéric Engel-Gros (1843-1918), not only is Gulbenkian's entire collection intact, including the mina $\bar{\imath} \bar{\imath}$ ware, but the great majority of the documentation concerning the acquisition process survives as well. ${ }^{24} \mathrm{~A}$ study of the archival documents, together with the objects, provides a clearer view into the emergence of the market for such material, which is key to understanding how certain types of ware became commercially successful, widely collected, and thus - through a combination of advice, donations, and bequests-entered the collections of major museums of Islamic art. The holdings of these institutions have become canonical objects and have played a key role in the formation of a scholarly understanding of the field.
Gulbenkian initially bought from the leading dealers in Paris and London, most of whom were fellow Armenians. ${ }^{25}$ Later, he sought out pieces that had been in the hands of other major collectors, such as Walter Townley (1863-1945), Arthur Sambon (1867-1947), ${ }^{26}$ and Frédéric Engel-Gros, when they came up for sale at auction. ${ }^{27}$ While the focus here is primarily on the mina $\bar{\imath} \bar{\imath}$ ware that Gulbenkian acquired in the first two decades of the twentieth century, he also collected a variety of other classes of Islamic ceramics, as well as a large number of important carpets. Apart from a lifelong interest in İznik ware, which he always referred to as "Rhodian" ware despite Arthur Upham Pope informing him of his error in $1934,{ }^{28}$ he also engaged in buying Raqqa ware, Sultanabad ware, and Persian luster ware from the early twentieth century onward.

Gulbenkian's collection of minnă’ ware contains fifteen pieces, ${ }^{29}$ of which eight are ostensibly complete bowls. ${ }^{30}$ Of the sherds, only one is not a bowl base or some other part of a bowl. The exception is the fragmentary beaker acquired in 1914, the year after Henri Rivière (1864-1951) had published it in his La Céramique dans l'Art Musulman. ${ }^{31}$ In addition to miñằ̄ ware, Gulbenkian bought two complete items and one sherd of the related lajvardina ware. There is a much-restored turquoise jug, acquired in 1909 from Ter Serkassian for an unrecorded sum, ${ }^{32}$ and a superbly restored but largely complete cobalt blue bowl purchased in June $1921 .^{33}$ Formerly in the Engel-Gros collection, this bowl was significantly more expensive than any of Gulbenkian's pieces of miñ $\bar{a} \bar{\iota}$ ware. ${ }^{34}$

Gulbenkian had a business arrangement with the Armenian art dealer Hagop Kevorkian (1872-1962), ${ }^{35}$ which ran from 1896 to 1898 . The related papers, in Ottoman Turkish written in Armenian script, mention mina $\bar{a} \bar{\imath}$ ware, ${ }^{36}$ and it is likely during this period that Gulbenkian acquired his first examples. There are only five pieces of mina $\bar{\imath} \bar{\imath}$ ware that do not have a corresponding invoice in the archives of the Gulbenkian Foundation. One of them is a superb high-footed bowl base featuring a popular scene from Ferdowsi's Shāhnāma (Book of Kings), depicting the Sasanian ruler Bahram Gur out hunting on a camel, with his concubine Azadeh sitting behind him (fig. 1). ${ }^{37}$ There is also a small but very fine and seemingly unique white bowl rim sherd with four bands of small cursive inscriptions running across 

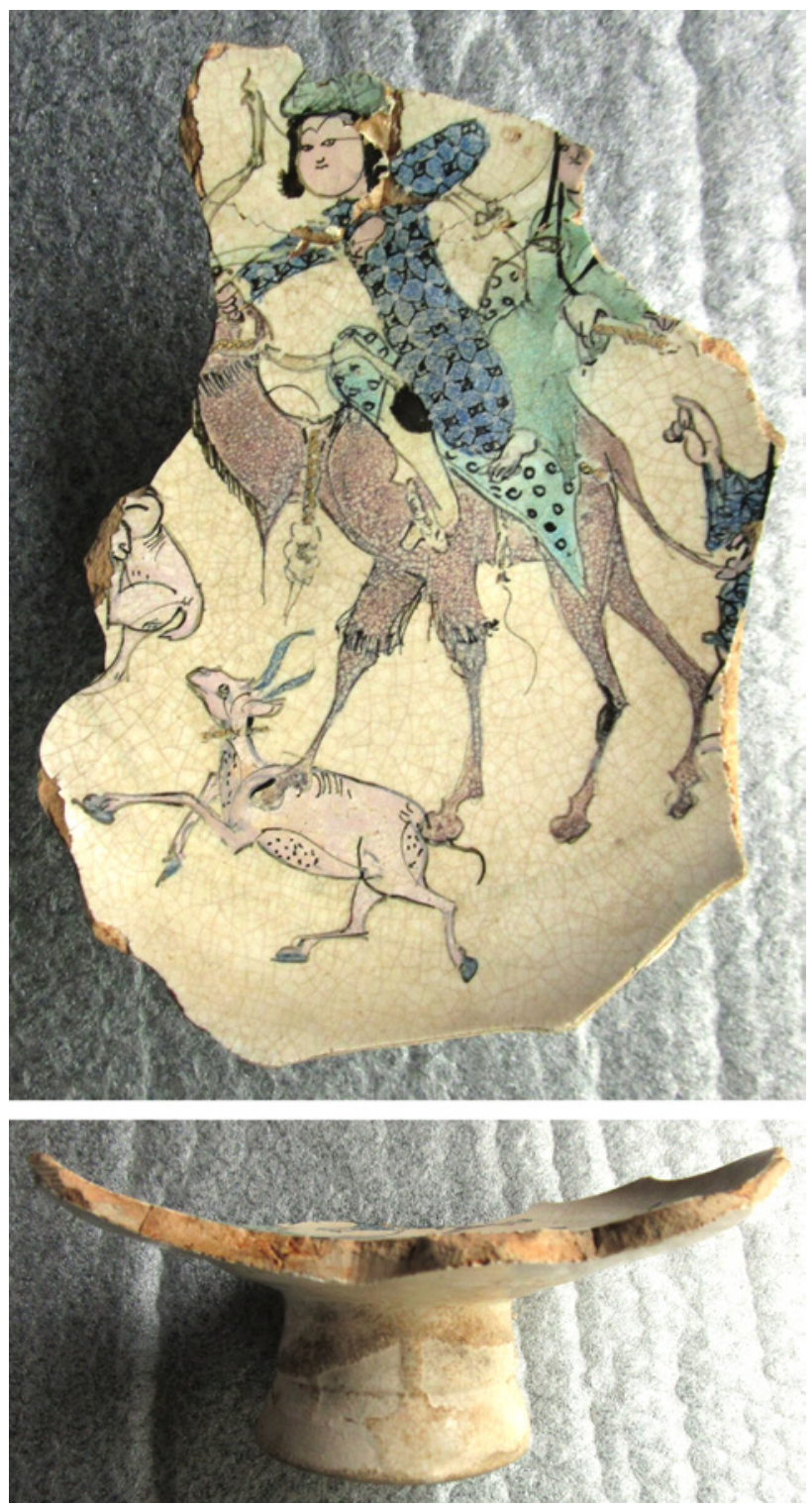

Fig. 1. High footed minnà $\grave{\imath}$ bowl base featuring Bahram Gur, Museu Calouste Gulbenkian, Lisbon (acc. no. 992). (Photo: Richard McClary)

it (fig. 2). ${ }^{38}$ Two other pieces without invoices, which may have been acquired from Kevorkian in the same period, are both seemingly complete bowls. One of these is the first of Gulbenkian's two "Style 1a" bowls, ${ }^{39}$ and the other is a "Style 7 " bowl with a large horseman (fig. 3)..$^{40}$ This latter bowl is one of the two in the collection that have newly fabricated ceramic sections with overglaze painted decoration that is close, but not identical in

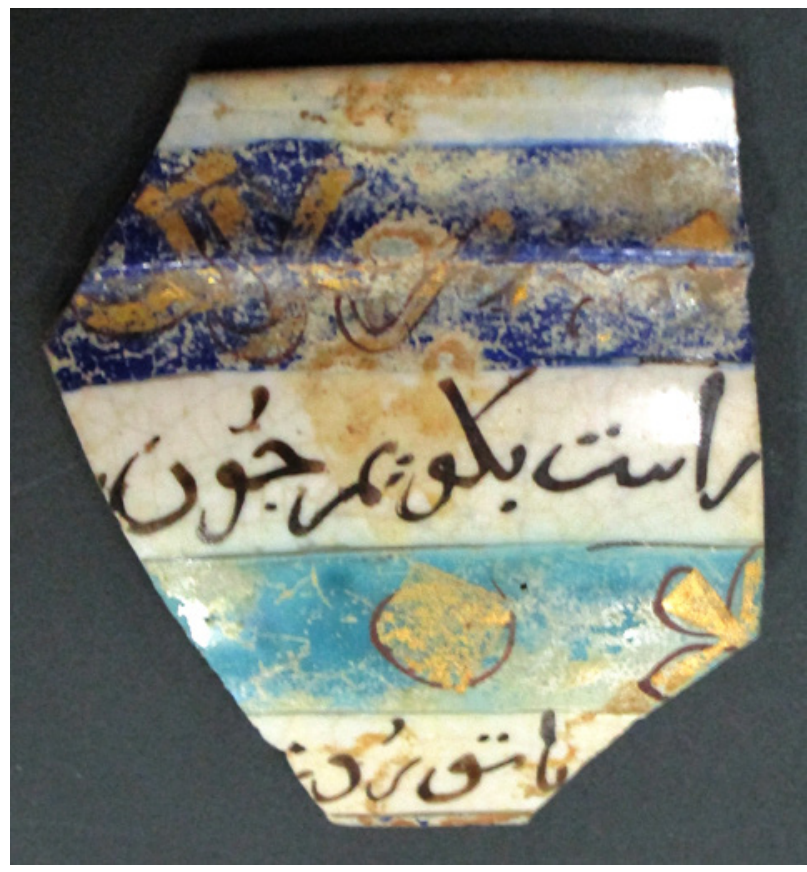

Fig. 2. Unique epigraphic minnā' Gulbenkian, Lisbon (acc. no. 998). (Photo: Richard McClary)

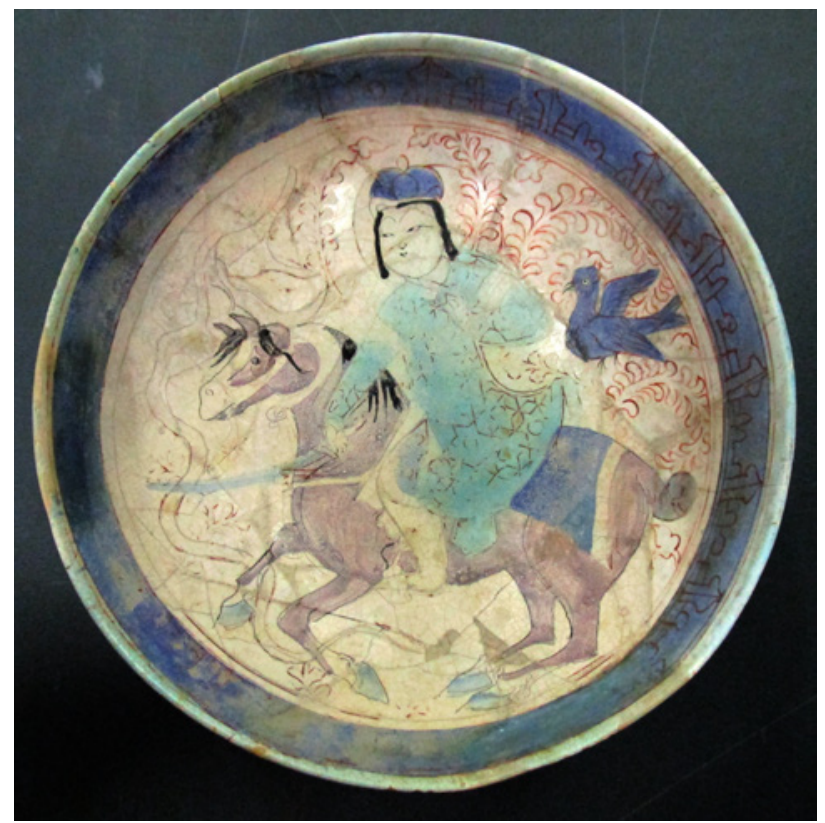

Fig. 3. "Style 7" bowl with large areas of newly fired sections in the area above and to the right of the rider, Museu Calouste Gulbenkian, Lisbon (acc. no. 931). (Photo: Richard McClary) 

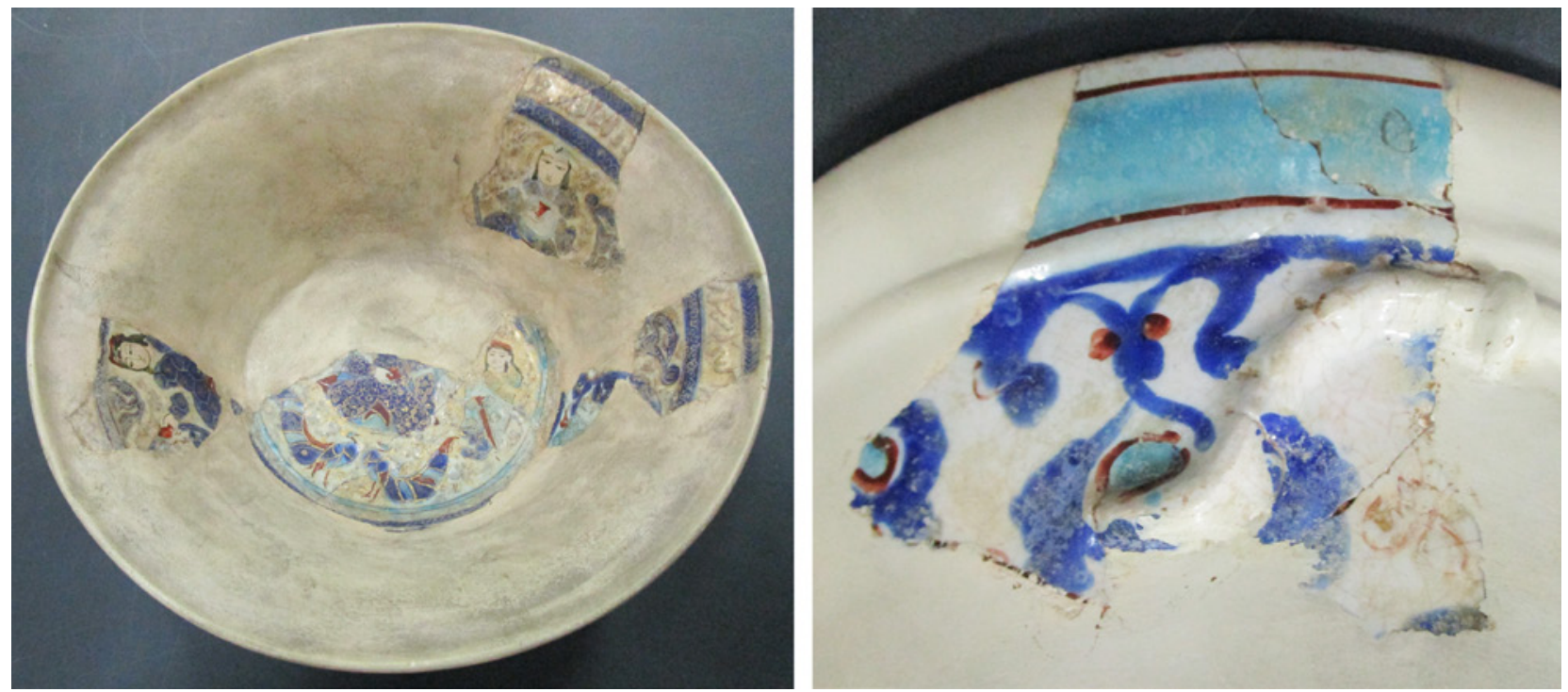

Fig. 4. Bowl sherds with "Style 6a" decoration on the inside (left), and "Style 1" on the outside (right), Museu Calouste Gulbenkian, Lisbon (acc. no. 997). (Photo: Richard McClary)

terms of color tone or fineness of line, to the surviving areas of original decoration. ${ }^{41}$ The fifth piece with no invoice consists of three wall sherds and part of the base of a large white bowl with relief decoration, all of which are set into an unpainted plaster matrix (fig. 4) ${ }^{42}$ If it was in the period from 1896 to 1898 that Gulbenkian acquired most, though not necessarily all, of these pieces, then we can conclude that he was willing to buy sherds as well as complete vessels from the very beginning of his interest in collecting minnà $\bar{\imath}$ ware, and prior to the publication of any images of such material. ${ }^{43}$ The majority of the pieces of minà $\bar{\imath}$ that he bought up to 1914 were fragments of vessels. Prior to the middle of 1914 , Gulbenkian had only bought three seemingly complete bowls; but afterward he bought this type of vessel exclusively, purchasing two bowls later that year, and another two in 1921.

After ceasing to buy miñà $\bar{\imath}$ ware, Gulbenkian broadly followed the approach taken by the leading British collector of Islamic ceramics, Frederick DuCane Godman (1834-1919), ${ }^{44}$ and focused on purchasing Ottoman İznik ware, of which a significant amount of complete, unrestored, and non-archaeologically sourced examples were available, owing to their more recent origin. Following the death of Godman, Arthur Upham Pope went to great lengths in his attempt to secure the collection for Gulbenkian, but to no avail. ${ }^{45}$
In the nine years for which there is documentation for Calouste Gulbenkian's acquisition of mina $\bar{\imath} \iota$ ware, running from 1912 to 1921, he only purchased intermittently. Minnà $\bar{\imath}$ ware was clearly not a major focus of his collection as he only bought one bowl in 1912, a heavily repaired and repainted white lobed-edge "Style 2" bowl with a seated ruler in the middle (fig. 5$){ }^{46}$ This was purchased from Hagop Kevorkian for $£ 595,{ }^{47}$ equivalent to 15 , 015 francs at the time, with a further $£ 8$ o spent on restoration. ${ }^{48}$ In 1913 Gulbenkian bought a "Style 1c" bowl base, with a seated ruler and attendants, which also has a few reattached sherds of the lower portion of the inscription band on the rim (fig. 6). ${ }^{49}$ This came from Kalebdjian Frères in Paris ${ }^{50}$ and cost 1,0oo francs (fig. 13). ${ }^{51}$ The figures are halfway between miniature and monumental, ${ }^{52}$ and although it is a rather crudely painted example, the somewhat larger scale of the throne upon which the ruler sits allows for a clearer understanding of details than is possible with the more common miniature ones. The throne sits low to the ground on bulbous feet, and the finials have decorative bases below the largely missing tips. ${ }^{53}$

It was not until the following year, in 1914, that Gulbenkian would acquire the bulk of his collection of minā $\bar{\imath}$ ware. Again, the first purchase, in March, was from Kalebdjian Frères in Paris and consisted of three sherds. Of these, two were bowl bases ${ }^{54}$ that cost 1,400 


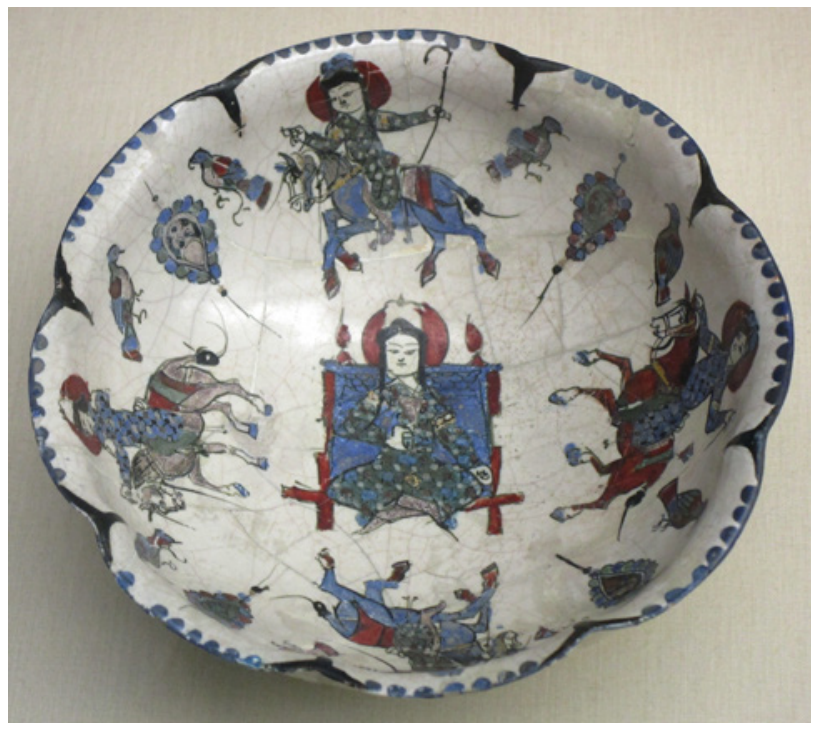

Fig. 5. "Style 2" bowl purchased from Hagop Kevorkian in 1912, Museu Calouste Gulbenkian. Lisbon (acc. no. 935). (Photo: Richard McClary)

francs each, and both, like all his purchases up this point, were on a white base glaze. One, which had been published by Henri Rivière the previous year, ${ }^{55}$ has a most unusual feature. The area around the rider in the base is pierced with numerous irregularly shaped holes filled with clear glaze in order to create something similar to the contemporary Seljuq pierced white ware, but with the addition of colored figural decoration. ${ }^{56}$ These small translucent areas surround the horse and rider in the center, which is entirely delineated in red. This is another most unusual technique, since in almost every other case the outline drawing of figures is in black. ${ }^{57}$ When the base is held up to the light, the area around the rider glows (fig. 7). When the bowl is on the ground, a similar effect is created by the ring of gold triangles delineated in red in the form of a starburst around the rider. It must have been characteristics such as the piercing that drew Gulbenkian to acquire such sherds, as he clearly had a connoisseur's eye that recognized their uniqueness and importance, the fragmentary nature of the pieces notwithstanding.

The other bowl base sherd ${ }^{58}$ features the lower body of a large rider and the upper portion of a horse. Gulbenkian clearly had an interest in the bowls with larger figures; three months later, in June 1914, he bought two minā $\bar{\imath}$ bowls from L. A. Raffy in Paris for a total of 50,000

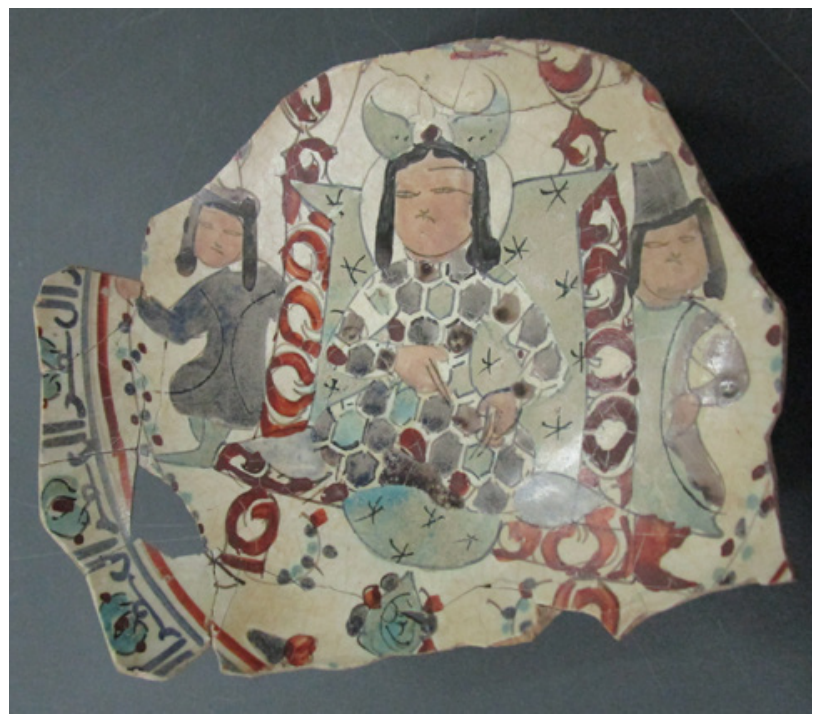

Fig. 6. "Style 1c" bowl base, Museu Calouste Gulbenkian, Lisbon (acc. no. 993). (Photo: Richard McClary)

francs. ${ }^{59}$ One of these ${ }^{60}$ was an extensively repaired and overpainted, but striking and important, bowl featuring two monumental seated figures (fig. 8). The large figures have superbly painted robes with vegetal designs, the original scheme of which was red and gold for the male figure; and black, turquoise, and gold for the female. ${ }^{61} \mathrm{In}$ addition, the hand and foot of the female figure display detailed henna decoration. ${ }^{62}$ The braided hair of the female figure extends out and up into the inscription band (fig. 9), presaging the similar expansion of the image out of the picture and into the text in later examples of Persian miniature paintings in manuscripts. ${ }^{63}$ The inscription band is an inversion of the standard "Style 7 " band, which has gold Kufic with a red border on a blue band. In the case of the bowl purchased from Raffy, the Kufic is blue, with red outline, and the background was gold, although only limited traces of the gilding remain (fig. 9). The exterior of the bowl has a large blue arabesque pattern, which runs over another arabesque pattern in gold with a red outline. There is also a turquoise band at the top with a cursive inscription in thin red script, with a gold border above and below. This bowl cost 35,000 francs, yet the other bowl that Gulbenkian bought at the same time ${ }^{64}$ is a far more original and wellpreserved piece. Less than twenty percent of the body of this fine example of a "Style $2 b$ " bowl is plaster fill, and 

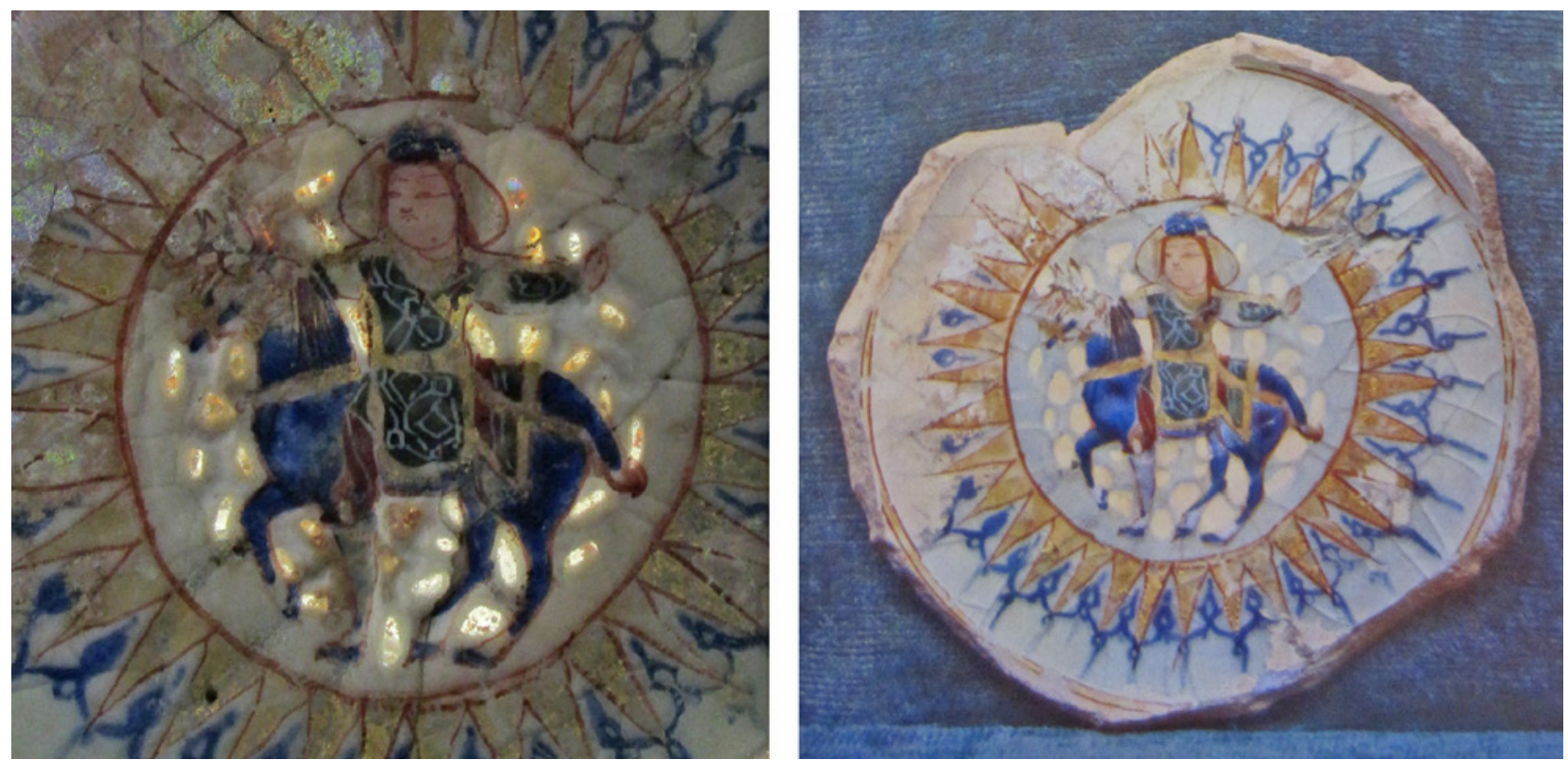

Fig. 7. Pierced min̄à $\bar{\iota}$ bowl base held up to the light (left) (Photo: Richard McClary); and as published by Henri Rivière in La Céramique dans l'Art Musulman (Paris: Librairie Centrale des Beaux-Arts, 1913), pl. 50 (right), Museu Calouste Gulbenkian, Lisbon (acc. no. 996).
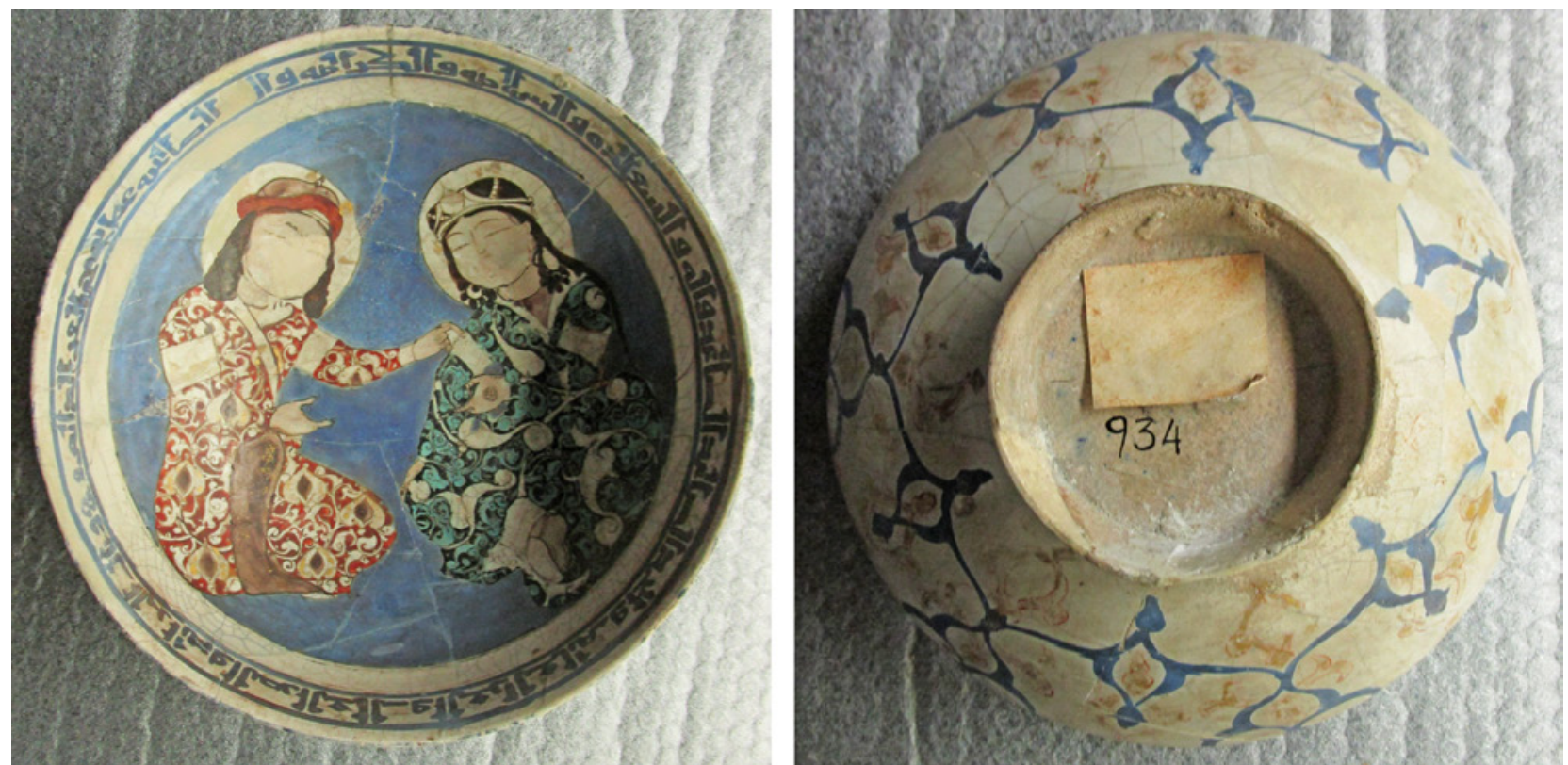

Fig. 8. Variant of a "Style 7" bowl with paired monumental figures, bought from L. A. Raffy in 1914, Museu Calouste Gulbenkian, Lisbon (acc. no. 934). (Photo: Richard McClary) 


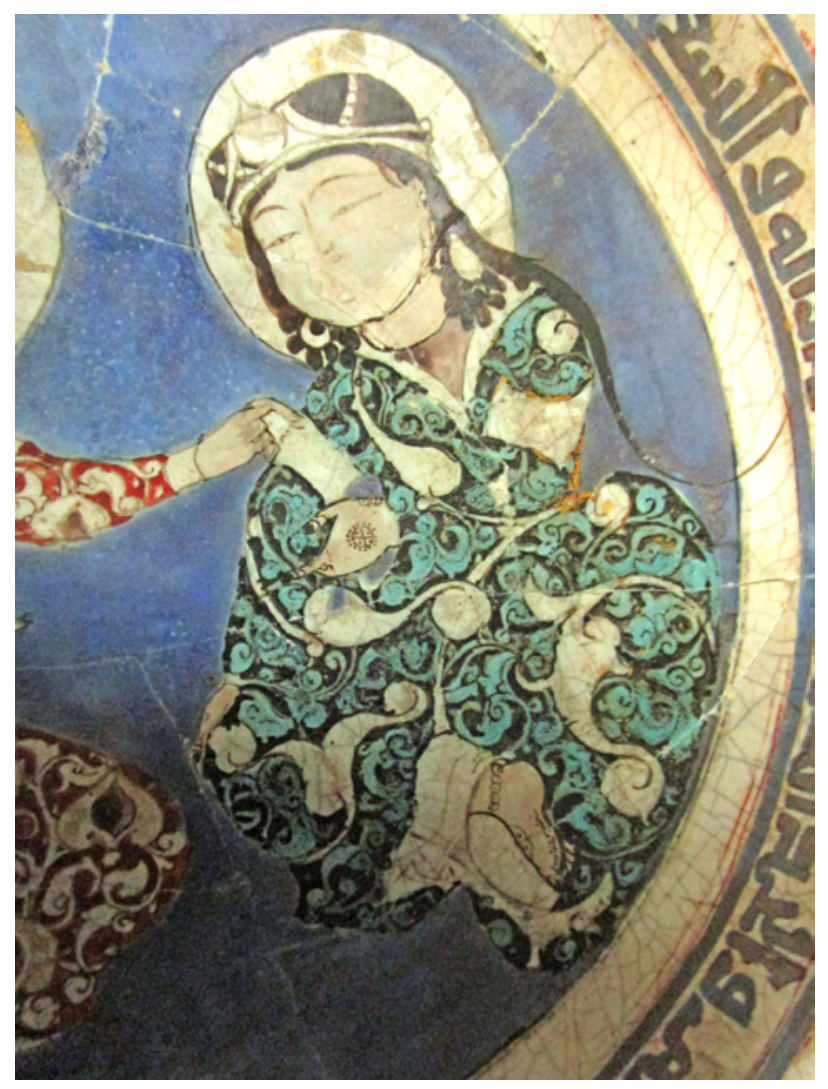

Fig. 9. Detail of the female figure on the bowl in fig. 8 . (Photo: Richard McClary)

it features exquisitely painted miniature decoration with an enthroned ruler in the middle (fig. 14). At 15,000 francs, this bowl was less than half the price of the other one he bought from Raffy at the same time. Gulbenkian had inserted a marker in his copy of the Friedrich Sarre (1865-1945) and Frederik Robert Martin (1868-1933) catalogue of the Munich exhibition of 1910, at the page that shows an almost identical bowl. ${ }^{65} \mathrm{He}$ appears to have purchased the first seemingly well-preserved example of a similar style bowl that came on the market. Given the very close stylistic similarities between the two, it is likely that his "Style $2 b$ " bowl was produced at the same workshop as the two sherds of the "Style $2 b$ " beaker he had acquired earlier in the same year. ${ }^{66}$ What this massive price differential shows is that there was a far greater value attached to monumental figural ware than to miniature examples, ${ }^{67}$ seemingly regardless of their condition or originality. This was to be the last time that Gulbenkian bought a piece of mina $\bar{\imath} \bar{\imath}$ ware directly from a dealer, ${ }^{68}$ and all the subsequent pieces he acquired came from auctions of existing collections purchased through agents. Such a practice was in line with his broader collecting policy of only buying the best, and therefore complete and undamaged, objects. ${ }^{69}$ Ironically, however, by purchasing seemingly complete pieces with established collector provenance from prestigious collections, Gulbenkian ended up buying far poorer quality pieces than when he was buying incomplete pieces from dealers that had no ownership history.

At the end of May 1914, Gulbenkian had bought what appear to be the final sherds of minnà $\bar{\imath}$ ware to enter his collection, namely the two pieces of the upper section of a "Style $2 \mathrm{~b}$ " beaker ${ }^{70}$ that had been published by Rivière the previous year (fig. 10). ${ }^{71}$ This marked a shift in his acquisition process. Previously, Gulbenkian had always bought directly from either Hagop Kevorkian, Ter Serkassian, or Hagop and Garbis Kalebdjian, but in this instance he used Kalebdjian Frères as agents to purchase the item at the auction of the Arthur Sambon collection at Galerie Georges Petit in Paris. ${ }^{72}$ This was the last fragmentary vessel that he was to purchase, but it is far from clear if it was the sherds in particular that he wanted. Just two lots earlier in the same sale ${ }^{73}$ was the largely intact beaker that is now known as the Freer Beaker. ${ }^{74}$ It had previously been in the possession of the Paris-based art dealer Georges Tabbagh ${ }^{75}$ and was sold for 43,45 o francs. ${ }^{76}$ The next lot was another minā̄ $\bar{\imath}$ beaker, which sold for 11,500 francs. ${ }^{77}$ It is unclear why Gulbenkian chose not to authorize his agents, Hagop and Garbis Kalebdjian, to buy either of the complete beakers, but following this purchase he only ever bought seemingly complete $\bar{m} \bar{\imath} \bar{a} \bar{\imath}$ ware bowls. Gulbenkian paid a total of 2,310 francs for the sherds. The hammer price was 2,000 francs, with a ten percent buyer's commission paid to the auctioneer, Georges Petit. The remainder of the cost was the five percent commission charged by Kalebdjian Frères; coincidentally, Gulbenkian himself was known as Mr. Five Percent due to his business practices in the then nascent, but already hugely profitable, oil industry. ${ }^{78}$

For reasons that remain unclear, Gulbenkian contracted another agent to represent him at the same sale, and it was Graat et Madoulé ${ }^{79}$ who supplied him with 

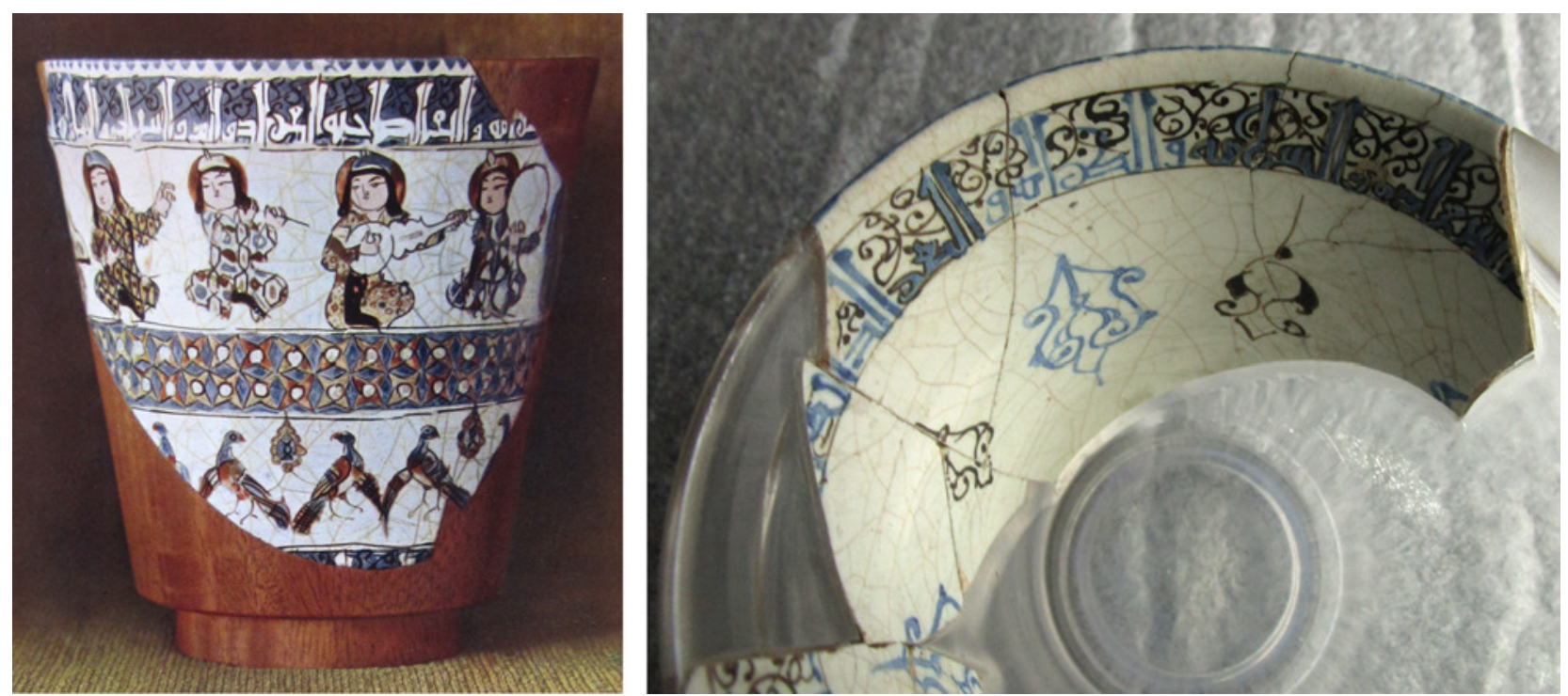

Fig. 10. "Style $2 b$ " beaker sherd as published by Henri Rivière in La Céramique dans l'Art Musulman (Paris: Librairie Centrale des Beaux-Arts, 1913), pl. 50 (left), and a detail of the interior inscription band (right), Museu Calouste Gulbenkian, Lisbon (acc. no. 999). (Photo: Richard McClary)

the other piece of minnà $’$ ware acquired from the Arthur Sambon collection when it was sold in 1914. For 1,925 francs, ${ }^{80}$ which was considerably less than the price of the "Style $2 b$ " beaker sherds, Gulbenkian got one of the finest examples of a "Style 1a" bowl in existence. ${ }^{81}$ It is a superb and virtually complete piece, ${ }^{82}$ yet it was not considered to be of any great value, presumably because the decoration is entirely non-figural (fig. 11). Perhaps this should not be surprising, as the archaeological record from numerous sites across Iran and beyond shows that far more figural wares were produced than nonfigural ones. ${ }^{83}$ This suggests that the demands of the market for minā' $\bar{\imath}$ ware in late-twelfth-century Iran were not dissimilar to those of early-twentieth-century Paris.

The sale of established collections of Islamic art, invariably as part of much larger and more diverse art collections, ${ }^{84}$ marked a shift and a maturation of the market for such material. For the first time, it presented a way for collectors to acquire material with at least some semblance of collector-or secondary-provenance, and to bypass the dealers who were primarily sourcing material directly from Iran, generally from local suppliers, buying up and repairing items that had been excavated clandestinely or commercially. Previously, these dealers only had each other as competition, and not auction houses as well as agents working for collectors, who hired them to bid for lots on their behalf. This created a true secondary market in Islamic art in Europe, and to a lesser extent in America, that worked alongside the network of dealers in Paris, London, and New York.

The shift from a situation where virtually all the material was sold by primarily Armenian dealers, who sourced material in Iran, to one that included the sale of privately held material at public auction brought the emerging market for Islamic art to a state of maturity, more akin to the market for European art and antiquities. ${ }^{85}$ This remains the primary mode of exchange through which the Islamic art market operates to the present day. ${ }^{86}$ The same pattern shown in Gulbenkian's purchase of minā $\bar{\imath}$ ware can also be seen in the records for his acquisition of Persian luster ware. Another Parisbased Armenian dealer that he used in the first decade of the twentieth century, albeit not for the purchase of minnà $\bar{\imath}$ ware, was A \& M Indjoudjian Frères, from whom he bought a luster tile for 600 francs in $1908 .{ }^{87}$ However, by the early 1920 Gulbenkian was sourcing his luster ware, as well as the last few pieces of mina $\bar{\imath} \bar{\imath}$ ware, from auction houses rather than dealers, with dealers being reduced to the role of agents. He used M. Kehyaian of London to acquire luster tiles from Sotheby's in 1922, as 


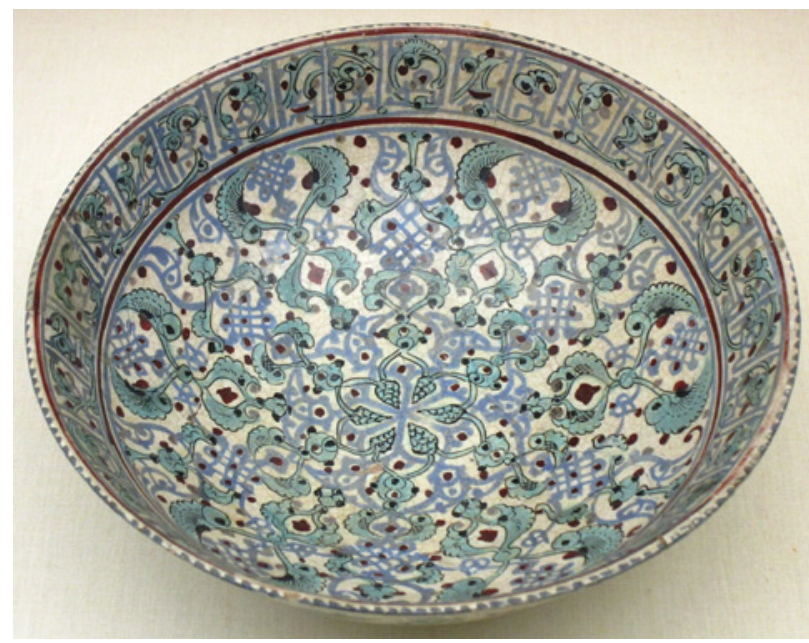

Fig. 11. "Style 1a" bowl purchased at the Arthur Sambon sale in 1914, Museu Calouste Gulbenkian, Lisbon (acc. no. 932). (Photo: Richard McClary)

well as an additional panel of luster tiles from Christie's the following year. ${ }^{88}$

Another factor that led to a shift away from dealers suppling material sourced in Iran was the reduced supply of high-quality items, owing to years of unregulated excavations and greater restrictions on the export of material from Iran. In 1934 Arthur Upham Pope notedperhaps not entirely without ulterior motive, given his role in the sale of such material - that the supply of fine Persian pottery was almost entirely shut off from Iran and had been for years. ${ }^{89}$ In addition, the first generation of collectors, who had begun acquiring material in the second half of the nineteenth century, were starting to pass away and the items in their collections were coming back onto the market in auctions.

At around the same time that established collections of Islamic art were starting to be sold at auction, other such collections were being donated to major museums. In 1917 the American industrialist and collector, Isaac D. Fletcher, bequeathed his extensive art collection to the Metropolitan Museum of Art in New York. ${ }^{90}$ It included eleven ostensibly complete pieces of minnà $' \bar{\imath}$ ware, all acquired before $1917 .{ }^{91}$ The bequest represented the first major private collection of mina $\bar{\imath} \bar{\imath}$ ware to be donated to a museum ${ }^{92}$ rather than being sold on the commercial market, as was the case with the far smaller collection of min $\bar{a} \bar{\imath}$ ware in the Sambon collection. ${ }^{93}$ It was from this point on that the relationship between wares excavated, repaired, and fabricated for the commercial market, on the one hand, and museums such as the Metropolitan Museum of Art, on the other, became completely and inextricably enmeshed.

The great majority of collectors were, and arguably still are, only interested in seemingly complete wares. However, alongside Calouste Gulbenkian, the American architect William Milne Grinnell (1858-1920) ${ }^{94}$ was one of the few early collectors of Islamic ceramics who showed a serious interest in amassing a collection of min $\bar{a} \bar{\iota}$ ware sherds. Grinnell bequeathed his collection of 239 ceramics to the Metropolitan Museum of Art in $1920 .{ }^{95}$ This included 30 minnă $\bar{\imath}$ ware sherds, almost all of which are bowl bases, along with three "Style 2" bowls, one "Style 6c" ewer, two tiles, and one "Style za" beaker. Although it is a large collection, none of the sherds are especially rare or outstanding in terms of either form or decoration. ${ }^{96}$

Many of the Armenian art dealers through whom Gulbenkian acquired material had built up large personal collections ${ }^{97}$ from which they lent items to major exhibitions and museums. As well as sourcing material for clients, they also published portions of their collections. The book by Dikran Kelekian (1867-1951), entitled The Potteries of Persia, features a bowl Kelekian had sold to Charles Lang Freer (1854-1919), alongside items from his own collection. ${ }^{98}$ Armenian dealers have been described as having cross-cultural advantages, ${ }^{99}$ as they boasted an enviable network of connections extending from the Armenian community in Tehran, throughout the Ottoman Empire to Paris, Cairo, New York, and London.

Calouste Gulbenkian did not buy any more examples of $\min \bar{a} \bar{\imath}$ ware until 1921, when he acquired his last two pieces, both from auctions of established collections, and both via agents. On the eighth of June, again through his agents Graat et Madoulé, he acquired his first, and only, piece of minnà̃ on a turquoise base glaze (fig. 12). The "Style $3 \mathrm{a}^{\text {" bowl }}{ }^{100}$ was bought at the Engel-Gros collection sale at Galeries Georges Petit in Paris, and cost Gulbenkian 36,425 francs. ${ }^{101}$ There was clearly a premium placed on turquoise ware, as they are far less common, both in terms of the market in early twentiethcentury Paris, and in the archaeological record. The decoration of the bowl is poorly painted and there are 


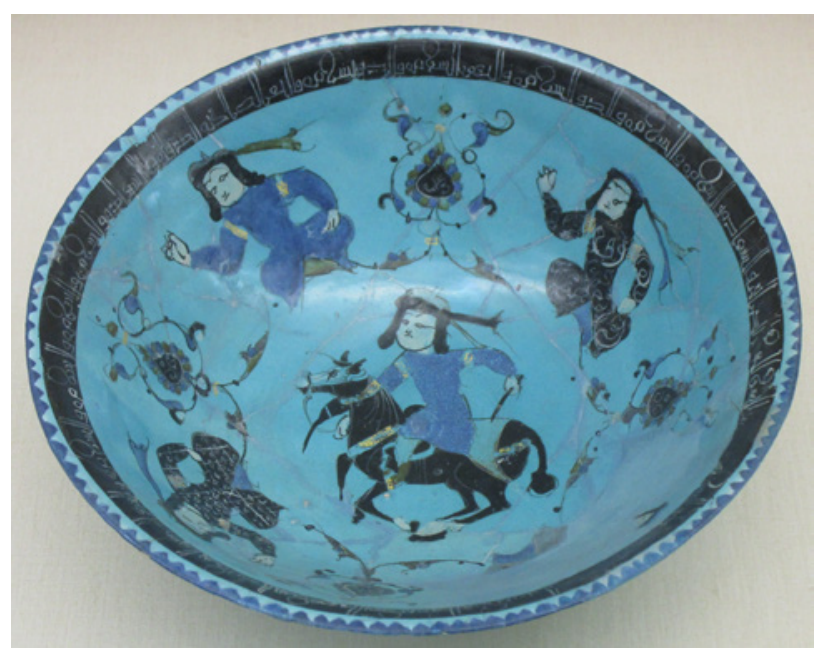

Fig. 12. "Style 3a" bowl bought at the Engel-Gros sale in 1921, Museu Calouste Gulbenkian, Lisbon (acc. no. 300). (Photo: Richard McClary)

large areas of plaster fill, ${ }^{102}$ but in this instance rarity clearly trumped quality. Gulbenkian must have wanted a piece of turquoise $\min _{\bar{a}} \bar{\imath}$ in his collection, as he had only acquired examples on a white base glaze up to that point. ${ }^{103}$

The last piece of mina $\bar{a} \bar{\imath}$ ware that Gulbenkian bought was a very poor-quality "Style $2 \mathrm{a}$ " bowl that had been in the Arthur Townley collection, and that was sold at Sotheby's later in June 1921. It was acquired for him by the London-based Armenian dealer M. K. Gudenian for $£ 270,{ }^{104}$ equivalent to 13,898 francs at the time. Following his purchase of the expensive and extensively repaired turquoise bowl earlier in the month, the acquisition of this "Style 2a" bowl appears to have put him off buying any more mina $\bar{\imath} \bar{\iota}$ for the rest of his life. It is likely that the poor quality of the repairs and overpaint of the "Style $2 \mathrm{a}$ " bowl, as well as the comparatively high price of the penultimate, and only turquoise, piece of mina $\bar{\imath} \bar{\imath}$ ware that Gulbenkian bought were a major factor in his loss of interest in acquiring further examples of the type. Subsequently, his interest in Islamic ceramics focused almost entirely on Sultanabad ware, as well as İznik and other related Ottoman ware, which he had always bought alongside the other types of Islamic ceramics in his collection. ${ }^{105}$ Superb examples of such ceramics were available in unrestored condition, as opposed to the mina $\bar{\imath} \bar{\imath}$ ware, which were all the product of clandestine or illicit excavations that turned up broken and usually incomplete vessels. These then required extensive repairs before they could be brought to market and sold as seemingly intact and complete wares.

Throughout the first two decades of the twentieth century, as we have seen, there was a clear shift in the source of Gulbenkian's acquisition of minnà $\bar{\imath}$ ware. He moved from the purchase of fragments or repaired wares from Armenian dealers, who were presumably sourcing the material directly from Iran, in the period from 1912 to 1914, towards the purchase of items from established European collections. A similar pattern can be seen in the purchasing habits of museums in America. The Pennsylvania Museum of Archaeology and Anthropology acquired two pieces of mina $\bar{\imath}$ from Hagop Kevokian in $1915,{ }^{106}$ but in April of the same year the museum also bought two minā' $\bar{c}$ bowls from the auction of the collection of Brayton Ives (1840-1914), held in New York following his death. ${ }^{107}$

After 1914, Gulbenkian only purchased complete restored min $\bar{a} \grave{\imath}$ vessels sold at auction from the holdings of other collectors, such as Arthur Sambon, Walter Townley, and Frédéric Engel-Gros; the latter two sales were held in 1921. His purchasing was done through the services of agents, such as M. K. Gudenian in London and Graat et Madoulé in Paris. It is not clear if this change in source was due to a reduction in supply available to dealers such as Kevorkian, ${ }^{108}$ or to a greater interest on the part of Gulbenkian in acquiring complete vessels from other collectors. Excerpts from the auction catalogue were glued to the invoice for the "Style 2a" bowl he bought from the Townley collection (fig. 13), and they show that a significant amount of detail was provided in the description by the auctioneers. ${ }^{109} \mathrm{Al}-$ though a photograph of the bowl is included on the invoice, because it is viewed from above, the extensive warping of the vessel is not at all clear. ${ }^{110}$

As we have seen, Gulbenkian owned copies of the Sarre and Martin catalogue of the Munich exhibition of $1910^{111}$ and the Riefstahl catalogue of the Parish-Watson Collection of Islamic ceramics, ${ }^{112}$ but perhaps the most influential was his copy of Rivière's La Céramique dans l'Art Musulman of 1913. This work included images of the beaker sherds Gulbenkian acquired the following year, as well as the pierced bowl base he bought from 

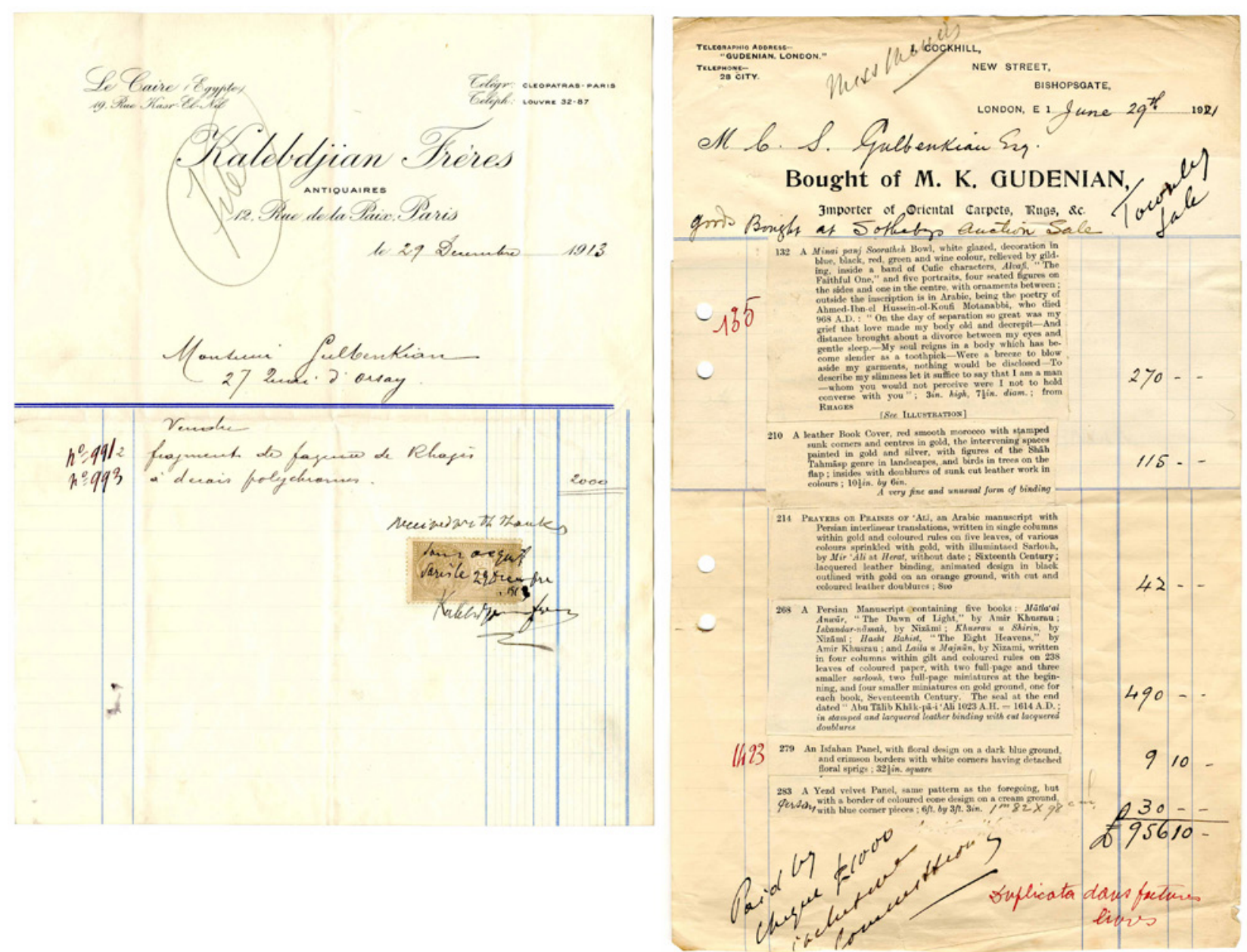

Fig. 13. Sales invoice from Kalebdjian Frères for two mīnā’̄ sherds sold in 1913 (MCGoo479) (left), and from M. K. Gudenian to Calouste Gulbenkian for items purchased at the Sotheby's auction of the Townley collection in 1921 (MCGoo284). (Images: courtesy Fundção Calouste Gulbenkian)

Kalebdjian Frères in March of 1914. ${ }^{113}$ It is clear that these publications not only raised awareness of the material, but also set the tone for what was deemed desirable by the small group of extremely wealthy collectors who were going after the limited number of restored pieces that were coming to market in the second decade of the twentieth century. ${ }^{114}$

Calouste Gulbenkian built up a significant, but by no means comprehensive, collection of minā $\bar{\imath}$ ware, which included some of the finest fragments, ${ }^{115}$ as well as two superb and largely intact pieces, his "Style 2 b" bowl and one of his "Style 1a" bowls (figs. 14, 11). ${ }^{116}$ The main lacu- nae from his collection are tiles, non-figural turquoise ware, and examples of most of the various types of molded and applied relief ware. ${ }^{117}$ These are almost entirely non-figural, and apart from the two "Style 1a" bowls, one of which was clearly purchased to provide a better quality example of the type, Gulbenkian appears to have had limited interest in non-figural minnà $\bar{\imath}$ ware. His interest in non-figural ware produced in the Islamic world was focused primarily on the purchase of the later Sultanabad and İznik ware, of which he built up an outstanding collection. ${ }^{118}$ His initial interest in buying sherds is indicative of a collector in pursuit of authenticity, and 


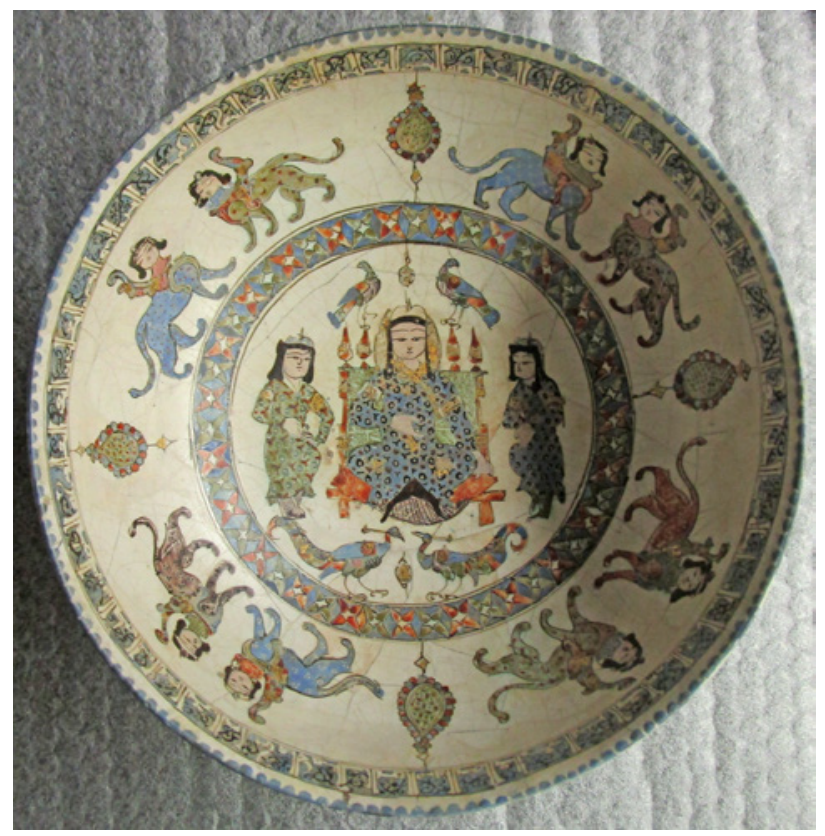

Fig. 14. "Style 2b" bowl purchased from L. A. Raffy in 1914, Museu Calouste Gulbenkian, Lisbon (acc. no. 938). (Photo: Richard McClary)

this process continued through most of the time he was acquiring examples of $\bar{m} \bar{i} \bar{a} \bar{\imath}$ ware. Once the market shifted and only apparently complete, but heavily restored, pieces were published and sold, he soon turned his attention towards more securely authentic material.

It is unquestionably the case, despite Arthur Upham Pope's claims to the contrary, ${ }^{119}$ that the honesty of sherds is lacking in the extensively restored vessels. However, the early-twentieth-century interventions have become part of the history of these objects, and while it is not necessary to preserve every single aspect, the areas of fill and overpaint were often a major contributing factor as to why many of the vessels were purchased in the first place. ${ }^{120}$ Such interventions speak to the way the commercial market for Islamic ceramics developed in the early decades the twentieth century and thus have historiographic value alongside the far greater value of the original constituent sherds from which the rest of the body of such minnà $\bar{\imath}$ vessels are made up.

When it comes to min $\bar{a} \bar{\imath}$ ware, the usual rules concerning provenance do not apply. Unlike most objects, the more an example of minā $\bar{\imath}$ has been owned by esteemed collectors, published in lavishly produced books, and exhibited at the most prestigious museums and exhibitions, the more likely it is to have been extensively altered, filled with plaster, and have large areas of the surface decoration painted in the modern era. This explains why it was precisely when Gulbenkian began to focus on buying wares with seemingly impeccable provenance, in terms of previous ownership, that he acquired some of the most inauthentic and heavily restored pieces in his collection. In contrast, the fragmentary wares and sherds largely lack any sort of provenance and were almost certainly illicitly excavated and then exported from Iran. ${ }^{121}$ Acquired directly from dealers such as Kevorkian, these sherds represent some of the most unique and important examples of mina $\bar{a} \bar{l}$ ware to have survived, their condition notwithstanding.

Despite the fragmentary nature of these wares, Gulbenkian had the eye of a connoisseur and clearly identified the importance of such material, even though the broader market, and eventually even Gulbenkian himself, fell under the spell of the fiction of completion. ${ }^{122}$ Unfortunately, as is becoming increasingly clear as museums around the world reassess their holdings of seemingly complete minnà $\bar{\imath}$ ware vessels, ${ }^{123}$ almost all of which were initially sourced from dealers, there is a price to be paid for the desire to acquire pieces with impossible levels of completion, especially in the context of entirely archaeologically sourced pre-Mongol wares. ${ }^{124}$ That price is a lack of honesty and authenticity in almost all of the examples that came to market in the first few decades of the twentieth century.

Department of History of Art,

The University of York,

York, England 


\section{APPENDIX}

\section{Overview of the Taxonomic Classification of Mīnā'̄ Ware}

\begin{tabular}{|c|c|c|c|c|}
\hline Style & Sub-Group & Name & Notes & Base Glaze \\
\hline \multirow[t]{5}{*}{ Style 1} & & Light-Blue Trellis & Vessels and tiles & White \\
\hline & Style 1a & & Geometric / arabesque & White \\
\hline & Style $1 \mathrm{~b}$ & & Some figural & White \\
\hline & Style 1c & & Mostly miniature figural & White \\
\hline & Style 1d & & Mostly monumental figural & White \\
\hline \multirow[t]{5}{*}{ Style 2} & & White Inscription on Blue & Sparse figural decoration & White \\
\hline & Style $2 \mathrm{a}$ & & Plain inscription band & White \\
\hline & Style $2 b$ & & Tendrils around letters & White \\
\hline & Style $2 \mathrm{c}$ & & Black lettering on blue & White \\
\hline & Style $2 \mathrm{~d}$ & & $\begin{array}{l}\text { Alternating blue, green, and red infill } \\
\text { around the lettering }\end{array}$ & White \\
\hline \multirow[t]{3}{*}{ Style 3} & & $\begin{array}{l}\text { White Inscription on a Black } \\
\text { Band }\end{array}$ & Figural or arabesque & Turquoise \\
\hline & Style $3 a$ & & Plain inscription band & Turquoise \\
\hline & Style $3 \mathrm{~b}$ & & Tendrils around letters & Turquoise \\
\hline Style 4 & & $\begin{array}{l}\text { Intricate Polychrome } \\
\text { Arabesque }\end{array}$ & Often paired with Style 3 band & Turquoise \\
\hline \multirow[t]{3}{*}{ Style 5} & & Intricate Miniature Figural & & Turquoise or White \\
\hline & Style $5^{a}$ & & Often paired with Style 3 band & Turquoise \\
\hline & Style $5^{b}$ & & Often paired with Style 2 band & White \\
\hline \multirow[t]{5}{*}{ Style 6} & & Relief & & Turquoise or White \\
\hline & Style 6a & & Gilded applied relief & Turquoise or White \\
\hline & Style $6 \mathrm{~b}$ & & Polychrome applied relief & Turquoise or White \\
\hline & Style 6c & & Molded & Turquoise or White \\
\hline & Style 6d & & Unglazed greenish clay body on jugs & None \\
\hline Style 7 & & Gold Kufic Inscription & Figural decoration & White \\
\hline \multirow[t]{2}{*}{ Style 8} & & Tiled Pattern & Only vessels & Turquoise or White \\
\hline & Style 8a & & Star and Cross Pattern & Turquoise or White \\
\hline Style 9 & & Luster and Minnā' $\bar{\imath}$ & Vessels and tiles & White \\
\hline
\end{tabular}




\section{NOTES}

1. This research would not have been possible without the award of a generous Visiting Scholar Fellowship from the Gulbenkian Foundation, undertaken in April 2019, which allowed me to access their archival material and closely inspect all their pieces of $m \overline{i n} \bar{a} \mathfrak{\imath}$ ware and other pre-Mongol ceramics. I am especially grateful to Penelope Curtis, Jorge Rodrigues, and Jessica Hallett for all of their help during my time in Lisbon. Most of the minna $\bar{\imath}$ ware in the Gulbenkian Collection was published in 1988 (see Maria Manuela Mota, Louças Seljúcidas [Lisbon: Museu Calouste Gulbenkian, 1988], 71-101), but this only consists of brief catalogue entries. Several pieces from the collection were not included in that publication, and are published here for the first time.

2. Margaret Graves, "Fracture, Facture and the Collecting of Islamic Art," in Faking, Forging, Counterfeiting: Discredited Practices at the Margins of Mimesis, ed. Daniel Becker, Annalisa Fischer, and Yola Schmitz (Bielefeld: Transcript, 2018), 91.

3. Ibid., 104.

4. Marshall Hodgeson's neologism "Islamicate" (see Marshall Hodgeson, The Venture of Islam: Conscience and History in a World Civilization. Volume 1: The Classical Age of Islam [Chicago: University of Chicago Press, 1974], 59) is not widely used, and most major auction houses now have an Islamic Art (or Indian and Islamic Art) department. The leading museums are either specifically museums of Islamic art-such as the Museum für islamische Kunst in Berlin, the Museum of Islamic Art in Doha, the Museum of the Islamic Era in Tehran, and the Islamic Arts Museum Malaysia in Kuala Lumpur-or are encyclopedic museums with Islamic Art galleries. The only exception is the Metropolitan Museum of Art in New York, which since 2011 has used a somewhat over-long combination of geographic and anachronistic nationalist terms, titling their collection "New Galleries for the Art of the Arab Lands, Turkey, Iran, Central Asia, and Later South Asia." The major museum of Islamic art in Istanbul is called the Türk ve İslam Eserleri Müzesi (Turkish and Islamic Arts Museum), founded in 1928.

5. The British orientalist Stanley Lane-Poole (1854-1931) published a work entitled The Art of the Saracens in Egypt in 1886. In the preface he notes that the terms "Arab" and "Mohammadan" art are both misleading, as the artists were seldom Arabs and were sometimes Christian. He adds that "Saracen" simply means "Eastern," and as the term was used universally to refer to Muslims in the Middle Ages, his usage implies the two ideas of Oriental and medieval (Stanley Lane-Poole, The Art of the Saracens in Egypt [London: Chapman and Hall, 1886], v). For a more detailed discussion of the adoption of the term "Islamic Art," see David J. Roxburgh, "Au Bonheur des Amateurs: Collecting and Exhibiting Islamic Art, ca. 1880-1910," Ars Orientalis 30 (2000): 32.

6. For the most detailed studies of the Meisterwerke muhamedanischer Kunst exhibition, see the essays in Andrea Lermer and Avinoam Shalem, eds., After One Hundred Years: The 1910 Exhibition "Meisterwerke muhammedanische Kunst" Reconsidered (Leiden: Brill, 2012), especially the contributions by Avinoam Shalem, Eva-Maria Troelenberg, and Lorenz Korn. A few years later, in 1914, Hagop Kevorkian arranged an exhibition of "Muhammedan-Persian" art in New York. See Exhibition of the Kevorkian Collection, Including Objects Excavated under His Supervision Exhibited at the Galleries of Charles of London at 718 Fifth Avenue in New York (New York, 1914). The catalogue has been digitized by the Brooklyn Museum and is available online at archive.org.

7. See Rudolf Meyer Riefstahl, The Parish-Watson Collection of Mohammedan Potteries (New York: Weyhe, 1922). At around the same time, Arthur Upham Pope (1881-1969) was made Advisory Curator of Mohammedan Art to the Chicago Art Institute. The first professor of Islamic art in the United States was Mehmet Aga-Oglu (1896-1949), who was appointed as chair of the History of Islamic Art at the University of Michigan in 1933.

8. For details on the ranking applied to different national or ethnic categories in the late nineteenth century, see Gülru Necipoğlu, "The Concept of Islamic Art: Inherited Discourses and New Approaches," in Islamic Art and the Museum, ed. Benoît Junod et al. (London: Saqi, 2012), 59-6o. 9. For details on the rationale and organization of the 1931 exhibition, see A. T. Wilson, "Introduction," in Persian Art: An Illustrated Souvenir of the Exhibition of Persian Art at Burlington House London 1937 (London: Hudson \& Kearns, 1931), xiii-Xv.

10. Arthur Upham Pope and Phyllis Ackerman, eds., A Survey of Persian Art from Prehistoric Times to the Present (London: Oxford University Press, 1938-39).

11. See, for example, the section devoted to the arts of the Islamic world in the 1914 Sambon sale held in Paris (Georges Petit, Catalogue des Objets d'Art... Formant la Collection de M. Arthur Sambon [Paris: Georges Petit, 1914], 36-50).

12. Roxburgh, Au Bonheur des Amateurs, 13, cites the room of Oriental objects in the sale of Adolphe Goupil's collection by Hôtel Drouot in Paris in April 1888.

13. Patricia Blessing, "Friedrich Sarre and the Discovery of Seljuk Anatolia," Journal of Art Historiography 11 (2014): 6.

14. For early examples, see Gaston Migeon, Manuel d'Art Musulman II. Les Arts Plastiques et Industriels (Paris: Alphonse Picard, 1907), 264 and the Sambon sale catalogue of 1914 (Petit, Catalogue des Objets d'Art, 37-41).

15. One of the earliest examples of the use of the term "minai" is in the catalogue for the Sir Walter Townley sale held at Sotheby's in June 1921. While still described as coming from Rhages, the item (lot 132) is called a Minai panj Sooratheh bowl. However, as late as 1931, Riefstahl was still referring to the material as Rhages polychrome pottery (Rudolf M. Riefstahl, "Islamic Stucco Sculptures," The Art Bulletin 13, no. 4 [1931]: 443).

16. See James W. Allan, "Abū'l Qāsim's Treatise on Ceramics," Iran 11 (1973): 115, 12 .

17. The term haft rang (or haft rangi) is now generally used to refer to the technique of tile production that emerged under 
the Timurids in the fifteenth century, but which flourished under the Safavids in Iran throughout the seventeenth century (Parviz Holakooei et al., "Application of WDXRF in the Provenance Studies of Persian Haft Rang Tiles: A Statistical Approach," X-Ray Spectrometry 42 [2013]: 105).

18. For the widely accepted division of contemporaneous Persian luster ware into monumental, miniature, and Kashan styles, see Oliver Watson, Persian Lustre Wares (London: Faber \& Faber, 1985), especially 45-109.

19. Arthur Upham Pope was the first to attempt a taxonomic categorization of mina $\bar{\imath} \bar{\iota}$ ware, based on the attribution of various styles to Rayy, Kashan, and Sava (Arthur Upham Pope, "VII. The Ceramic Arts," in A Survey of Persian Art from Prehistoric Times to the Present, vol. IV, ed. Arthur Upham Pope and Phyllis Ackerman, 7 vols. (Oxford: Oxford University Press, 1967), 1559-66, 1596-16o6, 1627-30). However, no definitive production sites have been found at any of these cities, and Pope's categories, which do not tally with the large corpus of archaeological sherds, are no longer in use. Mehdi Bahrami divided minā̄ $\bar{\imath}$ ware into two categories: white vessels from Kashan, and turquoise ones from Rayy (Mehdi Bahrami, Gurgan Faiences [Cairo: Le Scribe Egyptien, 1949], 64-66). He also attributed the work of Abu Zeyd to Sava. However, this division also does not stand up to a close examination of the painting and motifs seen on both colors of vessel. Peter Morgan identifies three types in the-albeit limited-holdings of minnà $\bar{\imath}$ ware in the Khalili Collection. These consist of: type 1, with relief decoration, non-figural; type 2 , without relief decoration, non-figural; and type 3, without relief decoration, figural (Peter Morgan, "Iranian Stone-Paste Pottery of the Saljuq Period: Types and Techniques," in Cobalt and Lustre: The First Centuries of Islamic Pottery, ed. Ernst J. Grube [London: Nour Foundation, 1994], 168). While Morgan's classification is useful, there is scope for a far more rigorous analysis of the wares surviving in the wider corpus, and the identification of a wider range of categories, in order to better examine this complex and diverse, but still poorly understood, body of material.

20. Written in a letter from Calouste Gulbenkian to the art historian Bernard Berenson, dated February 7, 1938 (in the archive of the Villa i-Tatti, Florence), quoted in Jessica Hallett, "Calouste Gulbenkian and the Rise of Islamic Art," in The Rise of Islamic Art 1868-1939 (Lisbon: Calouste Gulbenkian Museum, 2019), 13.

21. João Carvalho Dias, Islamic Art in the Calouste Gulbenkian Collection (Lisbon: Fundação Calouste Gulbenkian, 2003), 13 .

22. For an overview of the key pieces in his collection, see Dias, Islamic Art in the Calouste Gulbenkian Collection, especially 23-121.

23. Parish Watson, operating as Parish-Watson \& Co., was an art dealer based at 44 East $57^{\text {th }}$ Street in New York.

24. In contrast, Henry Walters, the great Baltimore-based collector, did not concern himself with documenting his purchases and did not want people to know how much he had spent on the items in his collection (William R.
Johnston, William and Henry Walters, the Reticent Collectors [Baltimore: The Johns Hopkins University Press, 1999], 137). 25. These included Dikran Kelekian, M. K. Gudenian, Hagop Kevorkian, Hagop and Garbis Kalebdjian, and Ter Serkassian. He also sourced other types of Islamic ceramics from additional Armenian art dealers, including A. and M. Indoudjian Frères, H. Kehyaian \& Co., Kikor Minassian, and Kouchakji Frères. A quarter of Gulbenkian's entire art collection came directly from Armenian dealers, while another third was acquired from private sales and auctions through Armenian agents (Jessica Hallett and Maïda Chavak, "The Gift of Ubiquity: Armenian Art Dealers and Their Networks," in The Rise of Islamic Art 1868-1939 [Lisbon: Calouste Gulbenkian Museum, 2019], 55). See ibid., 55-66 for a study of Armenian art dealers and their trading networks.

26. See Petit, Catalogue des Objets d'Art, 35-45, and facing plates, for the minā' $\bar{\imath}$ ware included in the sale.

27. This general trend in Gulbenkian's acquisition of Islamic items has also been recently noted by Jessica Hallett (Hallett, "Calouste Gulbenkian and the Rise of Islamic Art," 22).

28. Letter from Arthur Upham Pope to Calouste Gulbenkian, dated October 18, 1934 (MCG 01505).

29. Some items consist of multiple sherds from the same vessel but are counted as one here.

30. The term "ostensibly complete" is used here to describe seemingly complete pieces, which were sold, exhibited, and catalogued as single complete vessels, but, like almost all pieces of mina $\bar{\imath} \bar{\imath}$ ware, are in fact reconstructed vessels formed out of a combination of sherds from multiple vessels, with plaster fill and overpaint or newly fired ceramic sections inserted to fill the voids.

31. Henri Rivière, La Céramique dans l'Art Musulman (Paris: Librairie Centrale des Beaux-Arts, 1913), pl. $5^{\circ}$.

32. Acc. no. 937.

33. Acc. no. 302. There is a small area of plaster fill in the wall of the bowl, and a significant amount of the white overglaze painted decoration on the interior has been touched up with a much glossier paint that the original areas.

34. It had a total purchase price of 65,800 francs.

35. For a brief note on Kevorkian's life, see Stephen Vernoit, "Islamic Art and Architecture: An Overview of Scholarship and Collecting, c. 1850-c. 1950," in Discovering Islamic Art: Scholars, Collectors and Collections, ed. Stephen Vernoit (London: I. B. Tauris, 2000), 31.

36. The papers relating to this business arrangement are in the Gulbenkian Foundation archives (LDN oo17). I am grateful to Jessica Hallett for providing this information. The documents refer to Persian glazed ware in place of $m \bar{i} n \bar{a} \bar{\imath}$, and the mix of the different script and language must have been in order to ensure their correspondence was kept private (Hallett and Chavak, "Gift of Ubiquity," 57).

37. Acc. no. 992. For details of the scene depicted, see Abolqasem Ferdowsi, Shahnameh, trans. Dick Davis (London: Penguin Books, 2006), 6o4-5.

38. The sherd (acc. no. 998) measures $5.4 \mathrm{~cm}$ by $4.6 \mathrm{~cm}$, and is $3 \mathrm{~mm}$ thick. There are three lines of text on the exterior and 
four on the interior of the sherd. It is one of a group of five sherds, of which three are luster ware and one is a piece of the rim of a large turquoise lajvardina dish. It is likely that these five sherds are the ones referred to in an invoice for "5 Fragments faience" from Dikran Kelekian to Calouste Gulbenkian, dated April 9, 1909 (MCG 00505).

39. Acc. no. 897. For an overview of the new taxonomic classification system used throughout this article, see the appendix (this subject is expanded upon in far greater detail in chapter two of my forthcoming monograph on minà' $\bar{\iota}$ ware). For an image of the "Style 1a" bowl, see Mota, Louças Seljúcidas, 78-79.

40. Acc. no. 931.

41. This process was far more expensive than the more common plaster fill, as a complete new identical bowl needed to be made so that the missing areas of the original bowl could be replaced. This method allows the replaced sections of bowl to ring when tapped, in a way that plaster does not, and gives a more glossy and truly glazed finish that cannot be achieved with plaster. Despite this, the original crackle lines in the glaze stop at the edge of the new sections, which consist of the entire area above and behind the horse and rider. The other bowl with new ceramic sections is the lobed bowl acquired from Hagop Kevorkian in 1912 (acc. no. 935). In that example there are fictive crackle lines painted onto the new pieces, but the quality of the painting makes it clear that the areas with such lines are not original.

42. Acc. no. 997. The sherds have "Style 1" decoration on the outside, with "Style 6a" decoration inside, along with extensive areas of cobalt blue with angular gold patterns delineated in red, in the manner of later lajvardina ware. There are sections of two bow-shaped relief handles on the exterior, and a seated ruler in the middle of the base.

43. The first published images of minnà $\bar{\imath}$ ware are the five bowl bases in Migeon, Manuel d'Art Musulman, 264, fig. 215.

44. For details of Godman's collection, see J. Michael Rogers, "The Godman Bequest of Islamic Pottery," Apollo 120 (1984):24-31; and J. Michael Rogers, "A Group of Ottoman Pottery in the Godman Bequest," The Burlington Magazine 127.984 (1985): 134-45. Godman was a collector, ornithologist, and trustee of the British Museum. For a brief biography see: https:// research.britishmuseum.org/research/search_the collection_database/term_details.aspx?bioId $=86683$ (accessed March 13, 2020).

45. Six letters from Pope to Gulbenkian, dating between February 2, 1933 and August 13, 1933, highlight Pope's tremendous efforts to negotiate the sale of the Godman collection of ceramics to Gulbenkian (MCG 01505). The collection was eventually bequeathed to the British Museum after the death of Godman's daughter Edith in 1982.

46. Acc. no. 935 .

47. Hagop Kevorkian invoice to Calouste Gulbenkian, dated August 19, 1912 (MCG 00540). The invoice states that the bowl was excavated in Rhages (Rayy).

48. About a quarter of the bowl, on the right hand side, is newly made and fired ceramic with overpainted decoration to match the internal figures and animals, as well as the external cursive inscription.

49. Acc. no. 993.

50. The Armenian brothers Hagop and Garbis Kalebdjian opened their antiquities dealership in 1905 at 12, Rue de la Paix in Paris: https://www.doaks.org/resources/bliss-tylercorrespondence/annotations/kalebdjian-freres (accessed September 13, 2019).

51. Kalebdjian Frères, invoice to Calouste Gulbenkian, dated December 29, 1913 (MCG o0479). The invoice of 2,000 francs is for two sherds. The whereabouts of the other sherd, listed as acc. no. 991, is unknown, and it is no longer in the Museu Calouste Gulbenkian.

52. Using Watson's terminology developed for the categorization of the similar, but by no means identical, luster decoration applied to similarly shaped stonepaste vessels in Kashan at around same time. See Oliver Watson, Persian Lustre Ware (London: Faber \& Faber, 1985), 44-85.

53. Katherine Otto-Dorn, "Das Seldschukische Thronbild," Persica 10 (1982):149-203 is the most detailed study of Seljuq thrones, and makes extensive use of images of seated rulers on $\bar{m} \bar{i} \bar{a} \bar{\imath}$ ware in order to establish the main characteristics of the type. See especially page 155 for details of Ibn Bibi's account of wine drinking by the Rum Seljuq sultan 'Ala' al-Din Kaykubad while seated on his throne in Konya. See also the examples in 195, figs. 1, 1a; 198, figs. 12, 13; 199, figs. 15,16 ; and 202-3, figs. 25, 26, 28, 32. For reconstructions of the most common types of Seljuq thrones see 199, fig. 14 . See also ibid., ${ }^{1} 5^{8-59}$.

54. The whereabouts of the third sherd (acc. no. 995) is unknown, but all three are listed as Rhages ware on the invoice from Kalebdjian Frères, dated March 10, 1914 (MCG o.478).

55. Acc. no. 996. See Rivière, La Céramique, pl. 5 o.

56. See Oliver Watson, Ceramics from Islamic Lands (London: Thames \& Hudson, 2004), 310, for an example of such Seljuq white ware with regular holes cut into the body and filled with clear glaze. See also Mohammad Yousef Kiani, "Recent Excavations in Jurjan," in The Art of Iran and Anatolia from the $11^{\text {th }}$ to the $13^{\text {th }}$ Century A.D., ed. William Watson (London: School of Oriental and African Studies, 1974), pl. 5 for another example, excavated in Gurgan. Oliver Watson, "Pottery and Light," in God Is the Light of the Heavens and the Earth: Light in Islamic Art and Culture, ed. Sheila Blair and Jonathan Bloom (New Haven, CT: Yale University Press, 2015), 164 uses the term "transparencies" for the clear glaze-filled voids in the stonepaste body. Ibid., 166, fig. 137 shows a beaker in the Victoria and Albert Museum (acc. no. C.267-1919), with a similar form to examples decorated in $\bar{m} \bar{i} \bar{a} \bar{\imath}$, but plain white, apart from a thin blue band on the rim, with a wide band of pierced decoration around the upper portion of the vessel.

57. The use of red delineation instead of black is found in the contemporaneous manuscript illustrations of horsemen in a copy of the Kitab al-Baytara (Book of Farriery), produced in Baghdad and dated 606 (1210). The image, on folio 57 recto of Ahmet III, 2115, is in the Library of the Topkapı 
Sarayı Müzesi. See Richard Ettinghausen, Arab Painting (Geneva: Skira, 1977), 97.

58. Acc. no. 994.

59. L. A. Raffy, invoice to Calouste Gulbenkian, dated June 23, 1914 (MCG 01513).

6o. Acc. no. 934 .

61. Only traces of the gold remain. The glossy black layer on the textile of the female figure is thick enough to give a relief effect and is very similar in style to tile patterns on an unpublished "Style 8a" bowl base in the Museum für Islamische Kunst in Berlin (acc. no. I.3854).

62. This unusual detail is only found on one other piece, a sherd in the musée du Louvre in Paris (acc. no. OA6055), which shows a woman with henna decoration on her hand.

63. Early examples of this expansion of elements of the picture beyond the confines of the frame can be seen in many of the illustrations in a copy of Varqa va Gulshāh in the Topkapı Library (H.841), thought to date from circa 125o. See J. Michael Rogers, The Topkapı Saray Museum: The Albums and Illustrated Manuscripts (London: Thames \& Hudson, 1986), 50-51 and 55-63, figs. 21-42.

64. Acc. no. $93^{8}$.

65. Friedrich Sarre and Frederik Robert Martin, Die Austellung von Meisterwerken Muhammedanischer Kunst in München 1910 (Munich: Bruckmann, 1912), vol. 2, pl. 96.

66. The unique mottled effect on the green in-glaze colorant in both cases, normally only seen on areas of manganese purple, as well as the identical internal and external inscriptions, and the bands of four-pointed stars, all suggest that these vessels were produced in the same facility.

67. Although there are extensive areas of new material and paint, the invoice from Raffy to Gulbenkian describes the monumental figural bowl as "garante authentique céramique Perse époque Rhages" (MCG 01513).

68. Gulbenkian continued to acquire ceramics through the 1930s, especially İznik ware, via Arthur Upham Pope as an agent, but these were also pieces from other collectors rather than Pope's own stock.

69. A study of the large number of invoices in the archives of the Foundation show a general trend away from buying directly from dealers, and towards the acquisition of a wide variety of items from dispersed collections at auction houses from the 1920 onward.

70. Acc. no. 999 .

71. Rivière, La Céramique, pl. 5 o.

72. Kalbedjian Frères, invoice to Calouste Gulbenkian, dated May 28, 1914 (MCG 00477).

73. Lot no. 152. See Petit, Catalogue des Objets d'Art, 37 for a description of the beaker in the Sambon sale catalogue. The previous (unnumbered) page features two images of the beaker.

74. Acc. No. F.1928.2. The fragmentary cursive inscription on the rim, visible in early images under a thin and patchy blue layer (see Rivière, La Céramique, pl. 45), appears to have been painted over with thicker blue pigment at some point by the Freer Gallery. This has disguised both the inscription and the nature of the losses to the rim of the beaker. For studies on the beaker see: M. M. Diakonov, "Un Vase en faïence avec des illustrations de Shah-Namé," Traveaux de Departement Oriental, Musée de l'Hermitage 1 (1939): 317-26; Grace D. Guest, "Notes on the Miniatures on a Thirteenth-Century Beaker," Ars Islamica 10 (1943): 148-52; and Marianna Shreve Simpson, "The Narrative Structure of a Medieval Iranian Beaker," Ars Orientalis 12 (1981): 15-24. For a detailed study of the story depicted on the beaker, see Charles Melville, "Text and Image in the Story of Bizhan and Manizha: I," in Shahnama Studies I, ed. Charles Melville (Cambridge: The Centre for Islamic and Middle Eastern Studies, University of Cambridge, 2006), 71-96.

75. Georges Tabbagh was based at 8, Rue Rossini from 1912 until 1925, when he moved to 39, Rue Lafayette.

76. The beaker was subsequently sold to the Freer Gallery by Parish-Watson \& Co in 1928 (https://asia.si.edu/object/ F1928.2/, last accessed September 30, 2019).

77. New York Herald, May 27, 1914.

78. See Jonathan Conlin, Mr. Five Percent: The Many Lives of Calouste Gulbenkian, the World's Richest Man (London: Profile Books, 2019) for a study of Gulbenkian's life, with a focus on his business interests in the oil industry.

79. Graat et Madoulé were based in Paris and operated from 6 , Rue Godot de Mauroi, and 12 Rue de Sèze.

8o. Graat et Madoulé invoice to Calouste Gulbenkian, dated May 26, 1914 (MCG oo333).

81. Acc. no. 932 .

82. A small section of the rim is overpainted plaster fill, and another tiny section of the cavetto is also plaster.

83. See chapter five of my forthcoming monograph on $m \bar{i} n \bar{a} \bar{\imath}$ ware for details of the archaeological evidence for the types of ware found, and their distribution across the Islamic world and beyond in the thirteenth century.

84. See Petit, Catalogue des Objets d'Art for an example of the diversity of material acquired by a collector of the caliber of Sambon.

85. For details concerning the establishment of the European art market in the late eighteenth and through the nineteenth centuries, see Thomas M. Bayer and John R. Page, The Development of the Art Market in England: Money as Muse, 1730-1900 (London: Pickering \& Chatto, 2011). See also the essays in Susanna Avery-Quash and Christian Huemer, eds., London and the Emergence of a European Art Market, 1780-1820 (New Haven, CT: Yale University Press, 2019).

86. See William McQuillian and Brian Lucey, "The Validity of Islamic Art as an Investment," Research in International Business and Finance 36 (2016): 388-401, especially 39o, for a study of the current state of the Islamic art market.

87. MCG oo410, invoice dated January 9, 1908. A \& M Indjoudjian Frères were based at 21, Rue Le Peletier, Paris. The tile is registered as acc. no. 1561 .

88. The two tiles bought for Gulbenkian at the Sotheby's sale on June 13, 1922 (acc. nos. 1559 and 156o) cost 644 and 598 francs, respectively. The panel of tiles acquired at Christie's in June the following year (acc. no. 1562), cost £16o (MCG 00512 and MCG 00520 ). 
89. Letter from Arthur Upham Pope to Calouste Gulbenkian, dated October 18, 1934 (MCG 01505). As early as 1915, Dikran Kelekian had written to the collector Henry Walters and informed him that the main sites in Iran were already depleted, and that many of the pieces of Persian ware consisted of misassembled fragments for the market (letter from Kelekian to Walters, dated May 1915, in the Walters Art Gallery archive, quoted in Johnston, William and Henry Walters, 195 and $285^{-86}$ ).

9o. See Robert W. De Forest, "The Notable Bequest of Isaac D. Fletcher," Bulletin of the Metropolitan Museum of Art 12, no. 11 (1917): 216-18.

91. All the pieces have been heavily restored, and the collection includes one vase (17.120.253), one bottle (exhibited at the 1910 Munich exhibition, 17.120.2041), four small ewers (17.120.23, 17.120.44, 17.120.45, and 17.120.183), and five bowls (17.120.24, 17.120.40, 17.120.41, 17.120.42, and 17.120.252). Only two pieces are on a turquoise base glaze, namely the lobed edged "Style 3 b" bowl (17.120.410), and the "Style $3 a$ " ewer (17.120.45).

92. Earlier smaller donations of repaired vessels rather than unrestored mina $\bar{\imath}$ w ware sherds had previously been made to museums in Europe and North America, but not on a comparable scale.

93. There were six pieces of mina $\bar{\imath} \bar{t}$ ware in the Sambon sale, of which two were fragmentary. These consisted of a bowl base (lot 155), along with the beaker sherd acquired by Gulbenkian. See Petit, Catalogue des Objets d'Art, opposite page 40 for an image of the base. See ibid., opposite pages 36 and 38 for images of the other items of $m \bar{\imath} n \bar{a} \bar{\imath}$ ware in the sale.

94. Grinnell was an architect from New York who spent extended periods of time in Cairo. For more details, see Priscilla P. Soucek, "Building a Collection of Islamic Art at the Metropolitan Museum, 1870-2011," in Masterpieces from the Department of Islamic Art in the Metropolitan Museum of Art, ed. Maryam D. Ekhtiar et al. (New York: Metropolitan Museum of Art, 2011), 4.

95. J. B., "The William Milne Grinnell Bequest," The Metropolitan Museum of Art Bulletin 15, no. 12 (1929): 274.

96. Acc. nos. 20.120.112-141. All but two of the sherds are figural, and only two of them are on a turquoise base glaze.

97. Foremost among these were Hagop Kevorkian and Dikran Kelekian.

98. See Dikran Kelekian, The Potteries of Persia (Paris: Herbert Clarke, 19o9), 12, fig. 7 for one of his own miñ $\bar{\imath}$ ' ware bowls; and 13, figs. 8 and 9 for the Freer bowl. Ibid., 23 gives the English translation of the inscription on the Freer bowl. Kelekian's shop, called Le Musée de Bosphore, was located on Fifth Avenue in New York.

99. Vernoit, "Islamic Art and Architecture," 47.

100. Acc. no. 300.

101. Graat et Madoulé, invoice to Calouste Gulbenkian, dated June 1, 1921 (MCG 00357). It was lot 73, and was one of fifteen lots that Gulbenkian acquired in the Engel-Gros sale.

102. The plaster fill is color matched but not overpainted.
103. Gulbenkian had bought a turquoise lajvardina jug in 1909 (acc. no. 937), and also acquired a turquoise lajvardina dish rim sherd (possibly from Kelekian in 1909, as part of acc. no. 998), but he did not have any mina $\bar{\imath} \bar{\imath}$ ware on a turquoise base glaze.

104. M. K. Gudenian, invoice to Calouste Gulbenkian, dated June 29, 1921 (MCG oo284). Gudenian operated from 1 Cockhill, New Street, Bishopsgate, London.

105. Gulbenkian's first recorded purchase in Europe was of five İznik plates (Hallett, "Calouste Gulbenkian and the Rise of Islamic Art," 16-17).

106. These consist of a lion-handled spouted bulbous "Style $1 b$ " pot with a band of camels (acc. no. NEP9o), and a largely complete "Style $2 \mathrm{a}$ " cavetto bowl with a slightly off-center enthroned ruler (acc. no. NEP116). Both pieces were almost certainly excavated in Rayy by Kevorkian's agents in Iran.

107. Brayton Ives was the president of the Northern Pacific Railroad and the New York Stock Exchange. See Art Treasures Collected by the Late General Brayton Ives (New York: American Art Galleries, 1915). The two minnà' bowls, which have been extensively repaired, consist of a "Style 3a" carinated bowl (acc. no. NEP117) and a "Style 8" cavetto bowl on a white base glaze (acc. no. NEP119).

108. For anecdotal evidence of the reduced supply of wares from Iran, see both Pope's and Kelekian's comments on the subject in note 89 above.

109. The invoice for acc. no. 135 , sold as lot 132 at Sotheby's sale of the Townley collection in London in June 1921, includes the relevant page from the catalogue, which gives a translation of the poem on the outside of the bowl. There is also an image of the bowl (MCG OO284).

110. The true extent of the fragmentary nature of this bowl can be seen in the photograph taken after it was immersed in muddy water for twelve hours due to a flood in 1967 . The water dissolved much of the glue used to hold the numerous fragments together and the bowl fell apart. See Mota, Louças Seljúcidas, 17-21, especially 20, fig. 8.

111. Sarre and Martin, Die Austellung von Meisterwerken (D473).

112. Riefstahl, Parish-Watson Collection.

113. See Rivière, La Céramique, pl. 5o. Gulbenkian acquired his copy (LM243 A and B) in March 1914, the same month in which he bought the pierced bowl base (acc. no. 996) from Kalebdjian Frères.

114. Pope commented that the value of Persian pottery would rocket up following the publication of the Survey of Persian Art. He wrote this in a letter to Calouste Gulbenkian, dated October 18, 1934 (MCG 01505).

115. Acc. nos. 999 and 992.

116. Acc. nos. 938 and 932 respectively.

117. See the appendix for details of these categories.

118. See Maria Ribeiro, Iznik Pottery and Tiles in the Calouste Gulbenkian Collection (London: Scala, 2010) for the most recent study of Gulbenkian's collection of İznik ware. For images of two of his Sultanabad wares, see Maria Ribeiro, Islamic Art in the Calouste Gulbenkian Collection (Lisbon: Fundção Calouste Gulbenkian, 2003), 41-42. 
119. Mary McWilliams, "Collecting by the Book: The Shaping of Private and Public Collections," Muqarnas 20 (2003): 234, 25 o.

120. It is important to remember that glues and pigments degrade over time, and repairs that are obvious now were not necessarily so clearly visible in the early years of the twentieth century.

121. Several seemingly complete bowls retain their small pink paper export permits, pasted on by Iranian customs officials with the relevant sections filled in by hand. The fact that the paper extends over repaired sections in many cases proves that at least some of the major repair work occurred in Iran, prior to export.

122. It is worth noting that almost all of Gulbenkian's seemingly complete minn $\bar{\imath} \bar{\imath}$ ware bowls were displayed alongside complete examples of other types of wares, both glass and ceramic, in display cases in his home in Paris. It is not clear whether his sherds were displayed elsewhere in the house or were stored away out of sight. See Mota, Louças Seljúcidas, 16-17, figs. 3, 4 .

123. See Leslee Katrina Michelsen and Johanna Olafsdotter, "Telling Tales: Investigating a Mìnā' ing Islamic Art and Architecture: Essays in Honor of Renata Holod, ed. David J. Roxburgh (Leiden: Brill, 2014), 66-87 for a technical evaluation of a composite miñ $\bar{\imath} \bar{\iota}$ bowl formerly owned by Alan Balch and now in the Museum of Islamic Art in Doha (acc. no. PO.23o.MIAQ). See also Kimberly Masteller, "Arthur Upham Pope and Collecting Persian Art for Kansas City," in Arthur Upham Pope and a New Survey of
Persian Art, ed. Yuka Kadoi (Leiden: Brill, 2016), 277-81 for a study of two bowls supplied by Arthur Upham Pope in the Nelson-Atkins Museum of Art in Kansas. Graves, Fracture, Facture and the Collecting of Islamic Art, 99-104 features a similar example of extensive interventions made to a "Style 2a" bowl now in the Eskanazi Art Museum of Indiana University (acc. no. 6o.54). A detailed study of several of the pieces in the Metropolitan Museum can be found in Jean-Françoise de Lapérouse, Karen Stamm, and Vicki Parry, "Re-examination and Treatment of Mina'i Ceramics at the Metropolitan Museum of Art," in Glass and Ceramics Conservation 2007: Interim Meeting of the ICOM-CC Working Group, ed. Lisa Pelosi (Nova Gorica: Goriški Musej, 2007), 112-19. For similar issues concerning a contemporaneous luster ware vessel, see Francesca Leoni et al., "The Illusion of an Authentic Experience': A Luster Bowl in the Ashmolean Museum," Muqarnas 36 (2019): 229-49.

124. The only exceptions to this rule are the small number of pieces found intact inside a large storage jar in Gurgan, several of which are in the Ades Collection (Mehdi Bahrami, Gurgan Faiences [Cairo: Le Scribe Egyptien, 1949], 16). See ibid., pl. XXXI for a ewer now on display in the Victoria and Albert Museum, and pl. XXIV for a bowl now on display in the Fitzwilliam Museum in Cambridge. See also Géza Fehérvári, "The Gurgān Finds": A Loan Exhibition of Islamic Pottery of the Seljūg Period from the Raymond Ades Family Collection (London: Bluett \& Sons, 1976), 55, fig. 95 for another undamaged bowl from the same source. 